\title{
Increasing Consumers' Purchase Intentions Toward Fair-Trade Products Through Partitioned Pricing
}

\author{
David Bürgin ${ }^{1} \cdot$ Robert Wilken ${ }^{1}$
}

Received: 28 October 2020 / Accepted: 29 August 2021 / Published online: 13 September 2021

(c) The Author(s) 2021

\begin{abstract}
Selling fair-trade products can be problematic because of their higher price when compared with conventional alternatives. We propose that one way to solve this problem is to make consumers aware of the benefits of fair-trade. To this end, we perform three experimental studies to show that partitioned pricing (PP), which explicitly displays fair-trade as a separate price component, increases consumers' purchase intention toward the fair-trade product. This effect can be explained by increased perceptions of price fairness, which itself is mediated through transparency (but only if an additional verbal justification of the fair-trade price component is present). In the absence of such a verbal justification, recalled prices instead of transparency explain the positive effect of PP on consumers' purchase intentions. Interestingly, boundary conditions of this effect barely exist. Our incentive-aligned study illustrates that PP is associated with a $20 \%$ increase in purchases of fairtrade products. The results demonstrate an opportunity to increase the market share of fair-trade products, which increases social welfare and sustainability.
\end{abstract}

Keywords Fair-trade products $\cdot$ Partitioned pricing $\cdot$ Fairness $\cdot$ Purchase intention $\cdot$ Attitude-behavior gap $\cdot$ Price premium

\section{Problem Statement and Research Idea}

The fair-trade movement aims at promoting societal wellbeing by establishing prices for products that allow for living wages for workers (Fair-Trade Foundation, 2021a). Consumers have shown growing interest in purchasing products with such features (Andorfer \& Liebe, 2012; De Pelsmacker \& Janssens, 2007; Howard \& Allen, 2008; Stratton \& Werner, 2013). For example, worldwide revenues for fair-trade products increased by $1184 \%$ from 2004 to 2018 (Statista, 2018); for comparison, worldwide revenues for the general convenience food market predictably will increase by 161 from 2012 to 2025 (Statista, 2021), illustrating a strongly increasing demand. In this context, the Fairtrade International label is one of the most common and recognized ethical labels internationally (Fair-Trade Foundation, 2021b).

Robert Wilken

rwilken@escp.eu

David Bürgin

dbuergin@escp.eu

1 ESCP Business School Berlin, Heubnerweg 8-10, 14059 Berlin, Germany
However, research on ethical consumption still shows an attitude-behavior gap among consumers: They value ethical motives but do not behave accordingly (Andorfer \& Liebe, 2012; De Pelsmacker \& Janssens, 2007; Johnstone \& Tan, 2015). Hence, an unmet market potential remains for fairtrade products, likely because they are often more expensive than conventional alternatives (Bissinger, 2019; Marconi et al., 2017). The price difference is one major reason consumers do not purchase such products (Cailleba \& Casteran, 2010; Gleim et al., 2013), despite their benefits.

We, therefore, postulate that a problem in selling fairtrade products is not the absence of a reason to buy, even at a higher price. Instead, it might be whether and how the benefits of fair-trade products-attributes that matter to many consumers-are communicated. The core of such a communication is the applied pricing tactic itself. It is surprising that fair-trade product prices are usually displayed as "combined pricing" (CP); that is, the product's total price is listed without specifying any price component (Voester et al., 2017). We posit that partitioned pricing (PP), or dividing "the total price of an offering into two or more mandatory price components to generate favorable buyer response" (Voester et al., 2017, p. 880), can help communicate overlooked benefits to consumers (Bertini \& Wathieu, 2010). 
Applied to our case, PP would involve making a fair-trade price component explicit (by splitting the total price into a base price and a fair-trade price component). Although the price difference between fair-trade and conventional products would remain the same, changing the price format from CP to PP would highlight the fair-trade price component, thereby reminding the consumer of a valuable product attribute (Bertini \& Wathieu, 2008) and at the same time justifying the price difference from the conventional alternative. Moreover, consumers would perceive the price as more transparent (Hanna et al., 2019) and fair (Xia et al., 2004). Thus, with PP, fair-trade products could potentially sell more effectively in direct comparison to their conventional alternatives.

Surprisingly, the few studies that investigate consumers' purchase decisions regarding fair-trade products fail to explicitly investigate the role of pricing (Andorfer \& Liebe, 2012), although research shows ample support for the prominent role of prices in predicting consumer behavior in general (Allard \& Griffin, 2017; Haws et al., 2020). Therefore, the aim of this article is to investigate the role of price format (PP vs. $\mathrm{CP}$ ) in increasing consumers' purchase intentions towards the fair-trade product when consumers compare it with a conventional alternative. A sequence of empirical studies establishes this effect and explains it by perceptions of transparency and price fairness. We also rule out alternative explanations related to the pricing format of the conventional alternative and check for potential boundary conditions (e.g., purchase frequency in the fair-trade category). Finally, we test for external validity.

The next section presents the related literature in detail. This overview also identifies research gaps, which our research aims to fill.

\section{Research at the Intersection of Fair Trade and Pricing ${ }^{1}$}

We adopt an economical approach for investigating consumer behavior in fair-trade consumption (Andorfer \& Liebe, 2012). Accordingly, consumers, in comparing purchase alternatives, look at the respective benefits and prices. Importantly, this approach does not require the assumption of rationality; instead, both the perception of a product's benefits and its price are subjective and can be influenced (e.g., through advertising, framing, pricing). The highlight of the research idea is that an explicit price component (which actually represents a monetary sacrifice) can draw

\footnotetext{
1 This section focuses on consumers' perception of fair-trade prices. We refer the reader to Andorfer and Liebe (2012) and Moore (2004) for general overviews.
}

attention to a subjectively perceived product benefit and therefore even increase the value of the product (as the difference between benefit and price) over an alternative.

The price difference between fair-trade and conventional products is a major barrier and predictor for fair-trade preference and choice, as it decreases the fair-trade product's (perceived) value (Basu \& Hicks, 2008; Benson \& Connell, 2014; Cailleba \& Casteran, 2010; Cranfield et al., 2010). The price difference thus represents a competitive disadvantage (Ingenbleek, 2015; Johnstone \& Tan, 2015), especially when consumers do not understand it (Moser, 2015). Howard and Allen (2008) show that increasing the fair-trade price for strawberries on top of a reference price of $\$ 1.50$ by 3.33\% (\$0.05) to $100 \%$ (\$1.50) decreases consumers' willingness to pay (WTP) from $87.4 \%$ to less than $35 \%$. Yang et al. (2012) measure consumers' willingness to pay a premium for fair trade coffee, starting from a regular price of $\$ 3$. They show that more than $40 \%$ are willing to pay up to $15 \%$ more for fair trade, while only $4 \%$ would pay a price differential of $70 \%$ or more. Loureiro and Lotade (2005) illustrate that increasing fair-trade coffee price $(0-12 \%)$ over reference price of $\$ 6.5 / \mathrm{lb}$. decreases consumers' WTP as well.

At the same time, labelling a product "Fair-Trade" increases the product's value (Campbell et al., 2015; Cranfield et al., 2010), again reflecting the conflict between benefit and price. For example, research shows that consumers are in fact willing to pay between $\$ 0.22 / \mathrm{lb}$. and $\$ 1.40$ / lb. over a given reference price for fair-trade coffee (Hertel et al., 2009; Loureiro \& Lotade, 2005; Trudel \& Cotte, 2009), 22\% more for a cup of fair-trade coffee (Yang et al., 2012), $\$ 0.10 / 3.5 \mathrm{oz}$. for fair-trade chocolate, and $\$ 0.24 / 2 \mathrm{lb}$. for fair-trade bananas (Rousu \& Corrigan, 2008).

On average, research shows that consumers are willing to pay a higher price up to $10 \%$ ( $€ 0.19 / 0.5 \mathrm{~kg}$, reference price: $€ 1.87$ ) for fair-trade coffee (De Pelsmacker et al., 2005a, 2005b). Unfortunately (e.g., for chocolate), this is often smaller than the actual price charged (Didier \& Lucie, 2008), which only the minority of consumers is willing to pay (De Pelsmacker et al., 2005a, 2005b). Hence, typical price differences of $14 \%$ (and more) for fair-trade coffee (€11.67/ $\mathrm{Kg}$ conventional coffee, $€ 13.32 / \mathrm{Kg}$ for the fair-trade coffee) may be perceived as moderately overpriced (Cailleba \& Casteran, 2010; Wathieu \& Bertini, 2007). If the price difference exceeds $15 \%$ over the base price of a product with no fair-trade message, consumers' willingness to buy the fair-trade product decreases further (Rashid \& Byun, 2018).

This finding is consistent with studies that investigate negative feelings towards fair-trade products, given their price differences over conventional alternatives-resulting in reduced purchase likelihood. For example, the perceived lack of information about fair-trade products and the price difference are obstacles for ethical consumption, as they increase consumers' uncertainty and skepticism about 
the product (De Pelsmacker \& Janssens, 2007; Pedregal \& Ozcaglar-Toulouse, 2011; Uusitalo \& Oksanen, 2004).

In summary, extant literature has established the fair-trade price premium as a major barrier to consumer purchase (for an overview, see Appendix 2), which also (at least partly) explains the attitude-behavior gap. Still, the fair-trade attribute does offer benefit to consumers. However, extant literature has failed to offer strategies to mitigate the negative effects of higher fair-trade prices. In particular, we observe a lack of strategies that would explain or justify the price difference by activating the general willingness to engage in more ethical consumption. Therefore, this article's main contribution is to suggest and investigate such a strategy that is located at the core of the problem and at the same time acts as a communication tool: a pricing tactic (PP) that enables the retailer to communicate the fair-trade related benefit to the consumer, so that ultimately consumers evaluate the fair-trade product more positively.

\section{Hypothesis Development}

Various theories have been suggested to explain effects of price format (PP vs. $\mathrm{CP}$ ) on consumers: anchoring and adjustment theory, cost-benefit framework, prospect theory, and attribution theory (Voester et al., 2017). Anchoring and adjustment theory suggests that the bigger price component serves as an anchor, and the additional price component(s) are incorporated insufficiently, leading to an underestimation of the total price and improved price perceptions (Morwitz et al., 1998; Yadav, 1994). The cost-benefit framework suggests three strategies to process PP information: consumers can (1) recall the total price correctly (i.e., they integrate the price component(s) and the product price), (2) recall a lower price (i.e., they use the product price as an anchor and then heuristically adjust the price upwards), or (3) recall just the product price (i.e., they ignore the price component(s) completely) (Morwitz et al., 1998). This leads to neutral price perceptions for (1) and improved price perceptions (anchoring and adjustment theory) for (2) and (3). Prospect theory (Kahneman \& Tversky, 1979) suggests that prices are typically perceived as a loss, such that multiple price components represent multiple losses (i.e., monetary sacrifice), which favors CP over PP (Voester et al., 2017).

These theories represent an insufficient fit with our main argument: fair-trade offers a benefit to consumers instead of just an additional monetary sacrifice. The best fit instead is attribution theory (Weiner, 1986); it claims that "[c]onsumers strive to understand the reason for the existence of a [price component]. PP offers will be perceived differently depending on which causes consumers attribute to the occurrence of a [price component] and the behavior of the seller imposing it" (Voester et al., 2017, p. 888): namely, positive or negative (Koukova et al., 2012; Sheng et al., 2007). By attribution, the "[e]valuation of PP offerings can be more or less favorable than $\mathrm{CP}$ offerings depending on perceptions of the underlying reason for the appearance of the [price components]" (Voester et al., 2017, p. 888): profit [negative; Xia et al. (2004)] vs. external factors [e.g., benefit, positive; Bambauer-Sachse and Mangold (2010)].

When consumers compare alternative products for purchase, the economic approach suggests that they do so based on the alternatives' respective benefits and prices. The fairtrade product is usually more expensive than a conventional alternative. Therefore, consumers' purchase intentions will depend on their assessment of the additional benefit (that emerges through the fair-trade attribute), given the price difference. Importantly, studies show that consumers do value fair-trade as a product attribute (e.g., Basu \& Hicks, 2008); however, other studies show that the price difference is a major barrier for consumers to decide in favor of the fairtrade product (e.g., Cranfield et al., 2010).

Consequently, attribution theory applied to our context suggests that $\mathrm{PP}$, compared with $\mathrm{CP}$, helps consumers understand the higher fair-trade price better and increase their purchase intentions towards the fair-trade product:

H1 The relative purchase intention for the fair-trade product (compared with the conventional alternative) is higher with $\mathrm{PP}$ than with $\mathrm{CP}$.

To test the underlying mechanism of $\mathrm{H} 1$, we must determine whether consumers indeed attribute a positive reason to the higher price of the fair-trade product - that is, whether their attitude improves as a consequence of PP. "Attitude" is a key term here: it relates to a category mentioned in Voester et al., and and's (2017, p. 894) organizing framework. The previous argumentation suggests that consumers understand the price difference (between the fair-trade product and the conventional alternative) better under PP, resulting in a positive evaluation of that price difference.

In this context, perceived fairness of the price difference has received particular attention. It is a sensitive topic in the context of price evaluation (Xia \& Monroe, 2004) and especially important in our research context, as it requires an understanding of fairness in trade (McMurtry, 2009; Rios et al., 2015). People have many definitions of fairness (Lyn Cox, 2001), and literature shows that even when people have difficulty articulating what "fair" is, they still experience unfairness (Xia et al., 2004). We define price fairness as "a consumer's assessment of whether the difference (or lack of a difference) between a seller's price and the price of a comparative other party in a transaction is equitable, reasonable or justifiable" (Xia \& Monroe, 2010, p. 885). In contrast, the perception of unfairness is based on the belief 
that a company is making vast profits and acting unethically (Bechwati et al., 2009).

Therefore, prominently displaying a fair-trade price component through PP allows consumers to judge the adequacy of the price difference in terms of price fairness: PP for the fair-trade product should be evaluated as fairer than $\mathrm{CP}$ (Bechwati et al., 2009; Carlson \& Weathers, 2008; Ferguson, 2014; Sheng et al., 2007), increasing the purchase intention towards the fair-trade product (Campbell et al., 2015). Additionally, PP itself can positively influence the perception of fairness and thus the purchase intention (Carlson \& Weathers, 2008; Sheng et al., 2007).

In summary, price fairness is a key (attitudinal) construct that price format impacts. Therefore:

H2 Perceived fairness of the price difference between the fair-trade and conventional products mediates the effect specified in $\mathrm{H} 1$, such that the relative purchase intention for the fair-trade product (compared with the conventional alternative) is higher with PP than with $\mathrm{CP}$ because of higher perceived fairness for PP.

To complete the line of argumentation, we complement the model with a precondition so that evaluations of price fairness can actually happen. Such a completed model would also mimic the "perception and evaluation of prices and offerings" category in the Voester et al. (2017) framework.

For a construct that represents the underlying mechanism of the effect of price format on fairness perceptions, we turn to the availability heuristic. It implies that consumers use cues that are readily available for their evaluations (of offerings) (Folkes, 1988; Schwarz et al., 1991; Tversky \& Kahneman, 1973). Whereas PP specifies a separate price component for the fair-trade attribute (cue is present), with $\mathrm{CP}$, no such component exists (cue is absent) and therefore cannot be processed. PP makes the fair-trade attribute more prominent than under CP (in which the price difference from the conventional product is the only [implicit] information available about the added value of fair trade, and only implicitly). Hence, under CP, consumers cannot be certain that the price difference is solely related to fair trade itself because it would only be equal if all other product attributes-including brand, packaging, ingredients, and so on-were the same, which is rarely the case in mainstream supermarkets. Note that the base price for the fair-trade product could be lower or higher, compared with the conventional alternative, depending on the aforementioned influencing factors.

In this context, previous research has discussed transparency (Ferguson, 2014; Ferguson \& Ellen, 2013), defined as "the extent to which information about prices is available to buyers that ... explains ... the contextual direction and/or rationale for the seller's pricing" (Hanna et al., 2019, p. 228). It "enables buyers to predict and judge the relative appeal of the firm's present offer (i.e., what the customer gets in return for the price paid) compared to other competitive offers in the marketplace" (Hanna et al., 2019, p. 228). More specifically, price transparency occurs when the price structure is openly communicated to consumers - that is, under PP and not under CP.

Studies show various explanations of how PP relates to transparency; two seem plausible: (1) PP negatively influences transparency because consumers perceive that the company is trying to diffuse the total costs (Brown et al., 2010; Lee \& Han, 2002), ${ }^{2}$ and (2) PP positively influences transparency as it helps consumers understand the offering's costs and benefits (Bertini \& Wathieu, 2008, 2010).

In summary, and in line with our reasoning for $\mathrm{H} 2$, we posit that price format (PP vs. CP) positively influences transparency, as it makes consumers understand the costs and benefits of the offering better (Bertini \& Wathieu, 2008). Moreover, if transparency is valued positively, it should result in a greater perceived fairness (Bambauer \& Gierl, 2008; Homburg et al., 2014):

H3 Perceived transparency of the pricing mediates the effect specified in $\mathrm{H} 2$, such that the relative purchase intention for the fair-trade product (compared with the conventional alternative) is higher with PP than with $\mathrm{CP}$ because of higher perceived fairness for PP, which in turn is due to the higher perceived transparency of $\mathrm{PP}^{3}$

The argumentation so far presents the route through transparency and fairness as the main explanation of the positive effect of PP (vs. CP) on purchase intentions regarding fair-trade products. To challenge this assumption, we use a competing explanation so prominent in the PP literature that it is difficult to ignore: the cost-benefit framework.

This framework theorizes how consumers incorporate price components to recall the costs of an offering (Voester et al., 2017). We use the term "recalled prices" instead of "recalled costs" to emphasize the focus on price. Recalled prices are defined as "stating a single amount to represent the total price ... previously presented" (Carlson \& Weathers, 2008, p. 725). Consumers will recall lower prices for the PP offering, compared with the equivalent $\mathrm{CP}$ offering (Greenleaf et al., 2016; Kim, 2006; Lee \& Han, 2002;

\footnotetext{
${ }^{2}$ Lee and Han (2002) did not display the total price of the offering; instead they used an asterisk with an additional explanation of the surcharge, and Brown et al. (2010) hid the price component(s) comparably.

${ }^{3}$ Note that the mediated mediation is in line with Voester et al.'s (2017, p. 894, Fig. 1): Price format $>$ perception and evaluation of prices and offerings (here: transparency) $>$ attitudes and behavior beyond purchase (here: fairness) $>$ purchase-related behavior (here: purchase intention).
} 
Fig. 1 Research model. The additional factors are not "classic" control variables (i.e., they do not impact the dependent variable directly); rather they are moderators, according to the research model, and therefore might interact with price format (of the fair-trade product)
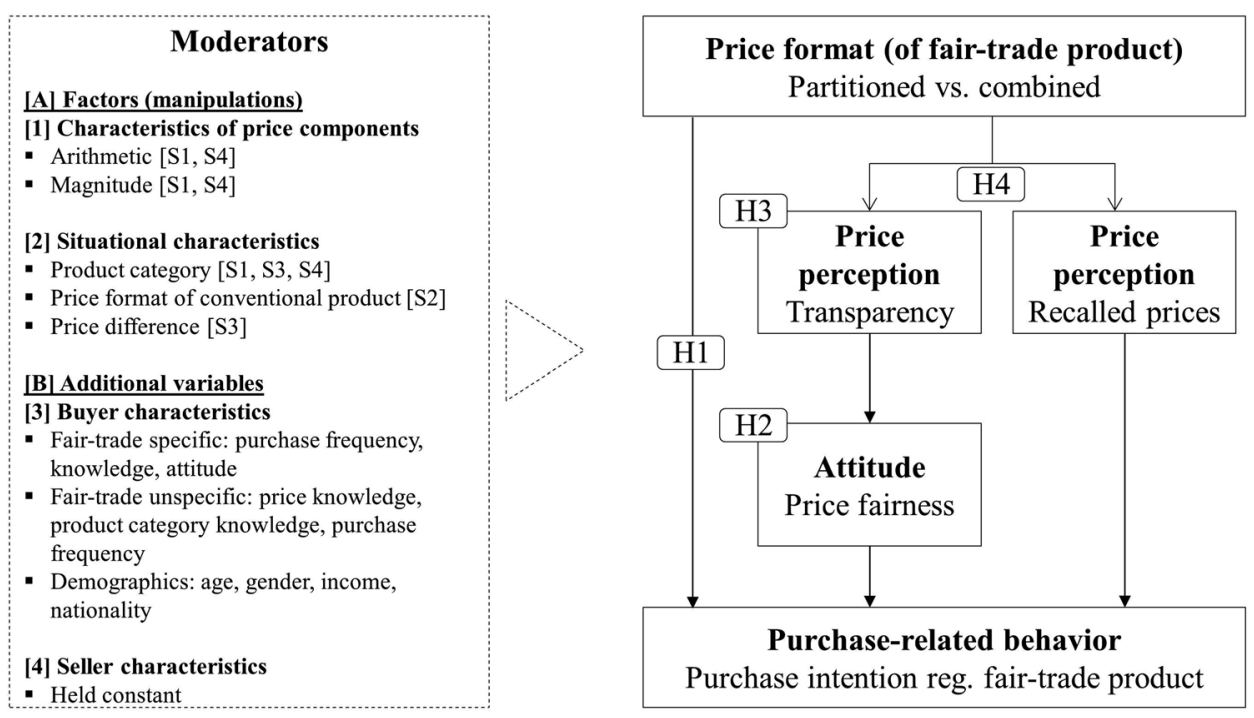

Morwitz et al., 1998). In turn, the lower perceived prices increase the attractiveness of the offer (Chakravarti et al., 2002), leading to increased purchase intentions.

Still, we favor the explanation that better fits the fairtrade context (more specifically, the fair-trade attribute as a source of consumer benefit). As a fair-trade price component (present in PP and absent in CP) would mirror a potential consumer benefit, it would probably be neither incorporated insufficiently nor ignored. It is more likely that "[price components] are processed accurately" (Voester et al., 2017, p. 888 ), leading to a neutral effect of price format (on purchase intention). Therefore:

H4 When comparing partitioned and CP for the fair-trade product, the difference in perceived transparency of pricing is greater than the difference in recalled prices for the fairtrade product. (As a consequence, the mediation of price format [partitioned vs. CP] on purchase intention through recalled prices is weaker than that through perceived transparency.)

We further include three types of moderators: (1) those unspecific to the research context (e.g., age, gender, income), (2) those specific to fair trade, and (3) those specific to the price format. We test these unspecific moderators for equal distribution across the respective experimental conditions, so that we can rule out their systematic effects on purchase intention. Regarding the fair-trade-specific variables, we check for interactions with price format and their potentially combined effects on transparency, fairness, and purchase intention. Last, as PP literature shows strong ambiguity regarding its advantageousness (Abraham \& Hamilton, 2018), we vary magnitude and arithmetic of the price component. The magnitude of the price component compares to the base price of the product and influences how consumers process price information (Voester et al., 2017). Larger (smaller) price components negatively (positively) influence consumers' perceptions of PP and hence their product evaluation (Sheng et al., 2007; Xia \& Monroe, 2004). The arithmetic of the price component (displayed as a percentage or in raw units) likewise influences consumers' processing of price information (Voester et al., 2017). More specifically, price components displayed in percentage of the total price are perceived more positively than those displayed in raw units (Bambauer \& Gierl, 2008; Kim, 2006). Figure 1 shows our research model, which structurally replicates Voester et al.'s (2017) framework and provides a summary of the hypotheses and the additional moderators.

\section{Empirical Studies: Overview}

\section{General Methods}

All studies use similar between-subjects experimental designs to test the hypotheses. We recruited all participants (except study 4's) through the panel provider Prolific, which previous research has shown to be a reliable data source (Peer et al., 2017), and excluded participants in case they had already participated previously. Very roughly speaking, we chose U.S. (study 1) and European (studies 2-4) subjects for reasons of presumed differences in the prevalence and thus acceptance of fair-trade products. Studies 2-4 are not based on samples from a specific European country but have each explicitly allowed a heterogeneous sample in terms of nationalities represented to make the test conditions stricter for the price format (because larger variances make it more difficult to detect significant differences).

The welcome page introduced the participants to the topic, emphasizing that there were no right or wrong answers 
and that the only goal was to get accurate information about their opinions and behavior (this served as an ex ante measure to avoid common method variance).

Whereas study 3 starts with the items to measure fairtrade-specific constructs (product category knowledge, price knowledge, fair-trade purchase frequency, fair-trade product purchase frequency, fair-trade knowledge, and fair-trade attitude), studies 1 and 2 include these items after the manipulation and the DVs. This might have created demand effects, but measuring these constructs after the manipulation would have created problems of endogeneity, and considering that $\mathrm{H} 1$ posits a comparison (i.e., assumes an increase in purchase intention), demand effects do not interfere with it. One advantage of varying the order of questions is the potential avoidance of common method variance.

The studies continued with exposure to one of the experimental conditions (see Table 1), either after having selected or being randomly assigned to one of two product categories (chocolate or banana, as these are among the best-selling fair-trade products by volume; Fair-Trade Foundation, 2021a, b, c, d; Statista, 2018). Table 1 highlights the systematically varied factors in each study in bold (the focal variable - the price format of the fair-trade product—is the only factor that varies in all studies).

We asked participants to examine the fair-trade product and its conventional alternative closely (see Fig. 2). We then measured key variables (transparency, fairness, purchase intention, and recalled prices) pertaining to the relative evaluation of the fair-trade product and the conventional alternative. Hereby, the measure for purchase intention used a semantic differential, while the others used Likert scales, possibly reducing common method variance (the exogenous construct was a manipulation anyway and therefore did not require any assessment on the part of the subjects). We also performed a manipulation check (study 1 ; we performed the manipulation check for studies 2 and 3 in a pretest). The study concluded by measuring additional control variables (unspecific to the fair-trade context: age, gender, nationality, and income). In study 4, we added purchase transactions.

The hypothesis tests in all studies use the following logic: For H1-H3, we fit Hayes's (2018) model 6; the total effect of price format (for the fair-trade product) on purchase intention is relevant to test $\mathrm{H} 1$, whereas for $\mathrm{H} 2(\mathrm{H} 3)$, we report the indirect effect through price fairness (transparency and price fairness). To test $\mathrm{H} 4$, we fit model 4 with two mediators (transparency and recalled prices included in one model, as their correlation is insignificant) and compare the respective coefficients (effects of price format of fair-trade product). We conclude with analyses pertaining to the additionally manipulated variables (see Table 1).

\section{Study 1: Implicitly Communicated Benefit and Average Price Difference}

Study 1 tests all hypotheses under strict test conditions: First, participants saw PP with no reinforcing benefit communication of the fair-trade attribute; only the Fairtrade International logo differentiates the fair-trade product from the conventional alternative. Second, the fair-trade products were presumably only moderately popular.

The price difference between the total prices of the fairtrade (\$2.99 [2.39] for chocolate [banana]) and the conventional product ( $\$ 2.49$ [1.99] for chocolate [banana]) was fixed ( $\$=0.50$ [0.40] for chocolate [banana], or 20\%). For consistency and to avoid a confound with price ending effects, which can be quite strong (Anderson \& Simester, 2003; Estelami, 1999; Manning \& Sprott, 2009), we adjusted the prices to be "similarly odd," The price format of the conventional alternative was CP. We further varied arithmetic (\$ vs. $\%)$ and magnitude $(10 \%, 17 \%$, and $20 \%)$ of the fair-trade price component. These specifications led to 14 conditions: 2 (products) $\times(1$ [price format of fair-trade product $=\mathrm{CP}]+6$ [price format of fair-trade product $=\mathrm{PP}$ ]), such that we had the six conditions in the case of PP for the fair-trade product split into 2 (arithmetic) $\times 3$ (magnitude).

\section{Sample Description}

The final sample included 294 U.S. participants, after excluding 110 who failed to correctly answer the manipulation check question. All prices were stated in U.S. dollars, to match the participants' nationality. The average age was 34 years, $52 \%$ were male; $46.3 \%$ had a disposable income between $\$ 20,000$ and $\$ 60,000,29.3 \%$ below $\$ 20,000$, and $24.4 \%$ above $\$ 60,000$. In addition, $52 \%$ described themselves as non-fair-trade buyers, $44.9 \%$ as occasional fairtrade buyers, and $3.1 \%$ as frequent fair-trade buyers. Most participants were somewhat or very familiar with the chosen product category $(81.3 \%)$ and its prices $(72.1 \%)$. The mean fair-trade knowledge was 3.85 on a 5-point Likert scale.

\section{Results}

Before testing the hypotheses, we checked the control variables for differences in means between the manipulations. All $p$-values (interaction between manipulation and control variable) fell between $p=0.185$ (product category knowledge) and $p=0.735$ (gender), so we do not consider them in the hypothesis tests. Table 2 shows the average purchase intention by experimental condition.

The total effect (model 6) of X (PP vs. CP) on Y (purchase intention regarding fair-trade product) with mediators $\mathrm{M}_{1,2}$ $\left(\mathrm{M}_{1}=\right.$ transparency; $\mathrm{M}_{2}=$ fairness $)$ is $0.9785(\mathrm{SE}=0.2772$; 
Table 1 Study overview

\begin{tabular}{|c|c|c|c|c|c|}
\hline \multirow[t]{2}{*}{ Setting } & \multirow{2}{*}{$\begin{array}{l}\text { Study } 1 \\
\text { Hypothetical }\end{array}$} & \multirow{2}{*}{$\begin{array}{l}\text { Study } 2 \\
\text { Hypothetical }\end{array}$} & \multirow{2}{*}{$\begin{array}{l}\text { Study } 3 \\
\text { Hypothetical }\end{array}$} & \multicolumn{2}{|l|}{ Study 4} \\
\hline & & & & Incentive-aligned & \\
\hline Product category & $\begin{array}{l}\text { Chocolate [branded], } \\
\text { Banana [non- } \\
\text { branded] }\end{array}$ & Chocolate [branded] & $\begin{array}{l}\text { Chocolate [branded], } \\
\text { Banana [non- } \\
\text { branded] }\end{array}$ & Chocolate [branded] & Banana [non-branded] \\
\hline Currency & USD & EUR & EUR & EUR & EUR \\
\hline $\begin{array}{l}\text { Total price } \\
\text { conventional product }\end{array}$ & $\begin{array}{l}2.49 \text { [chocolate] } \\
1.99 \text { [banana] }\end{array}$ & 2.49 & 1.99 & 0.87 & 1.15 \\
\hline $\begin{array}{l}\text { Price difference } \\
\text { conventional vs. fair- } \\
\text { trade (base: conven- } \\
\text { tional product) }\end{array}$ & $20 \%$ & $20 \%$ & $\begin{array}{l}\mathbf{1 0} \%, \mathbf{2 0} \%, \mathbf{3 0} \%, \mathbf{4 0} \% \\
\mathbf{5 0} \%\end{array}$ & $48 \%$ & $9 \%$ \\
\hline $\begin{array}{l}\text { Price format } \\
\text { FT product }\end{array}$ & $\mathbf{C P}, \mathbf{P P}$ & CP, PP & CP, PP & CP, PP & CP, PP \\
\hline $\begin{array}{l}\text { Price format } \\
\mathrm{CV} \text { product }\end{array}$ & $\mathrm{CP}$ & CP, PP & $\mathrm{CP}$ & $\mathrm{CP}$ & $\mathrm{CP}$ \\
\hline If price format $=\mathrm{PP}$ : & & & & & \\
\hline $\begin{array}{l}\text { Type of price compo- } \\
\text { nent } \\
\text { FT product }\end{array}$ & Fair-trade & $\begin{array}{l}\text { Tax, fair-trade, } \\
\text { tax + fair-trade }\end{array}$ & Fair-trade & Fair-trade & Fair-trade \\
\hline $\begin{array}{l}\text { Benefit communication } \\
\text { FT price component }\end{array}$ & Label only & Verbal & Verbal & Label only & Label only \\
\hline $\begin{array}{l}\text { Type of price compo- } \\
\text { nent } \\
\text { CV product }\end{array}$ & n.a & Tax & n.a & n.a & n.a \\
\hline $\begin{array}{l}\text { Arithmetic of FT price } \\
\text { component }\end{array}$ & USD vs. $\%$ & EUR & EUR & $\begin{array}{l}10 \% \text { in EUR, } 20 \% \\
\text { in } \%, 33 \% \text { in EUR }\end{array}$ & $\begin{array}{l}8 \% \text { in } \%, 10 \% \text { in } \%, 20 \% \\
\text { in EUR }\end{array}$ \\
\hline $\begin{array}{l}\text { Magnitude of FT price } \\
\text { component [base: } \\
\text { FT] }\end{array}$ & $10 \%, 17 \%, 20 \%$ & $17 \%$ & $\begin{array}{l}\text { Equals price differ- } \\
\text { ences: } 18.3 \%, 16.7 \% \text {, } \\
15.04 \%, 14.3 \% \text {, } \\
13.4 \%\end{array}$ & & \\
\hline Number of conditions & 14 & 8 & 20 & 4 & 4 \\
\hline Test of hypotheses & $\begin{array}{l}\mathrm{H} 1(\checkmark), \mathrm{H} 2(\checkmark), \mathrm{H} 3 \\
(\mathrm{x}), \mathrm{H} 4(\mathrm{x})\end{array}$ & $\mathrm{H} 1(\checkmark)$ & $\begin{array}{l}\mathrm{H} 1(\checkmark), \mathrm{H} 2(\checkmark), \mathrm{H} 3 \\
(\checkmark), \mathrm{H} 4(\checkmark)\end{array}$ & $\mathrm{H} 1(\mathrm{x})$ & $\mathrm{H} 1(\checkmark)$ \\
\hline $\begin{array}{l}\text { Main and interaction } \\
\text { effects according } \\
\text { to manipulated } \\
\text { moderators }\end{array}$ & $\begin{array}{l}\text { Product cat- } \\
\text { egory } \times \text { price format } \\
(\mathrm{FT}) \\
\text { Arithmetic, magnitude } \\
\text { Arithmetic } \times \text { price } \\
\quad \text { format }(\mathrm{FT}) \\
\text { Magnitude } \times \text { price } \\
\text { format }(\mathrm{FT})\end{array}$ & & $\begin{array}{l}\text { Product cat- } \\
\text { egory } \times \text { price format } \\
(\mathrm{FT}) \\
\text { Price difference } \\
\text { Price difference } \times \text { price } \\
\text { format }(\mathrm{FT}) \\
\text { Price difference } \times \text { prod- } \\
\text { uct category }\end{array}$ & & \\
\hline $\begin{array}{l}\text { Additional interaction } \\
\text { effects }\end{array}$ & $\begin{array}{l}\text { Purchase fre- } \\
\text { quency } \times \text { price } \\
\text { format }(\mathrm{FT})\end{array}$ & $\begin{array}{l}\text { Purchase fre- } \\
\text { quency } \times \text { price } \\
\text { format }(\mathrm{FT})\end{array}$ & $\begin{array}{l}\text { Purchase fre- } \\
\text { quency } \times \text { price } \\
\text { format }(\mathrm{FT}) \\
\text { Price differ- } \\
\text { ence } \times \text { income }\end{array}$ & & \\
\hline
\end{tabular}

$C V$ conventional product, $F T$ fair-trade

The systematically varied factors in each study are in Bold

$\mathrm{t}=3.53 ; p<0.01)$. The direct effect is $0.2436(\mathrm{SE}=0.2174$; $\mathrm{t}=1.1206 ; p>0.05)$, the indirect effect through $\mathrm{M}_{1}$ is 0.0064 ( $\mathrm{BootSE}=0.0222 ;$ BootLLCI $=-0.0336$; BootULCI $=0.0587)$, the indirect effect through $\mathrm{M}_{2}$ is 0.6428 (BootSE $=0.1768 ;$ BootLLCI $=0.3201$;
BootULCI $=1.0047)$, and the indirect effect through $\mathrm{M}_{1}$ and $\mathrm{M}_{2}$ is 0.0857 (BootSE $=0.0710$; BootLLCI $=-0.0464$; BootULCI $=0.2369$ ). These results support $\mathrm{H} 1$ and $\mathrm{H} 2$, but not $\mathrm{H} 3$; the price format did not influence transparency (coeff. $=0.1833 ; p=0.20$ ). 
Study 1

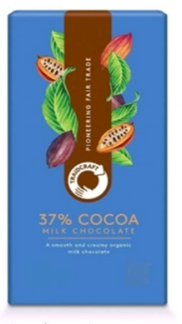

Product A

Product Price: $2.49 €$ per $100 \mathrm{~g}$

Total Price: $2.49 €$ per $100 \mathrm{~g}$

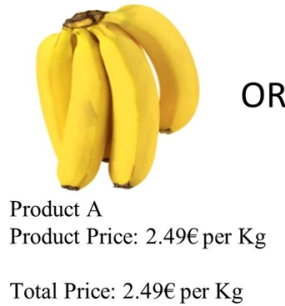

vs.

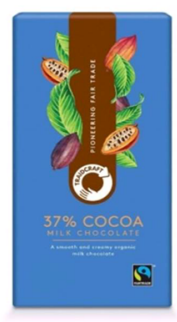

Product B

Product Price: $2.49 €$ per $100 \mathrm{~g}$

Fair-trade: $0.50 €$

Total Price: $2.99 €$ per $100 \mathrm{~g}$

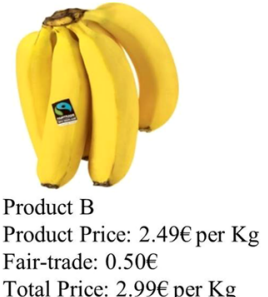

Study 3

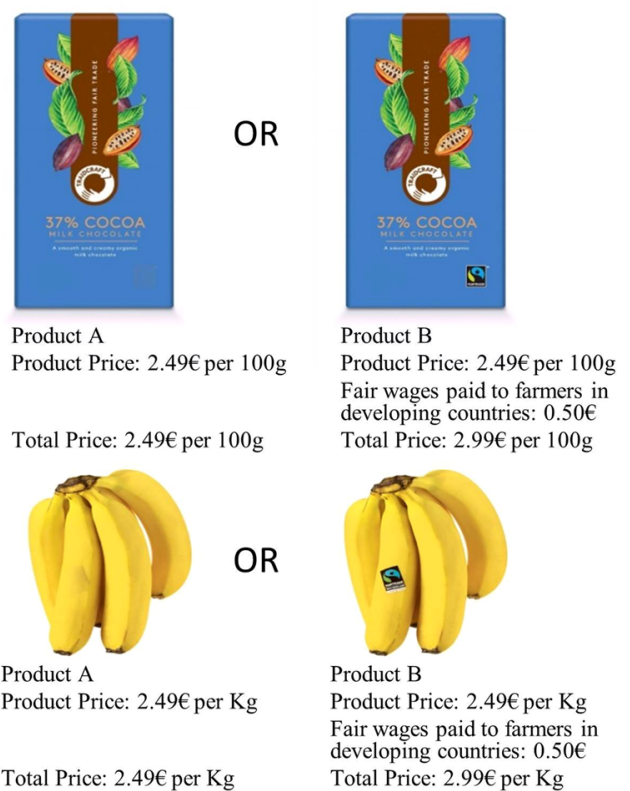

Fig. 2 Product manipulations. In study 1 (resp. 3), products were displayed without (resp. with) justification of the fair-trade price component

Table 2 Study 1: Cell sizes, manipulations, and average purchase intention by magnitude and arithmetic of the fair-trade price component

\begin{tabular}{|c|c|c|c|c|c|c|c|}
\hline Condition & Fair-trade, CP & $\begin{array}{l}\text { Fair-trade, PP, } \\
10 \% \text { in } \%\end{array}$ & $\begin{array}{l}\text { Fair-trade, PP, } \\
17 \% \text { in } \%\end{array}$ & $\begin{array}{l}\text { Fair-trade, PP, } \\
20 \% \text { in } \%\end{array}$ & $\begin{array}{l}\text { Fair-trade, PP, } \\
10 \% \text { in US\$ }\end{array}$ & $\begin{array}{l}\text { Fair-trade, PP, } \\
17 \% \text { in US\$ }\end{array}$ & $\begin{array}{l}\text { Fair-trade, } \\
\text { PP, 20\% in } \\
\text { US\$ }\end{array}$ \\
\hline $\mathrm{N}$ & 41 & 42 & 49 & 39 & 42 & 37 & 44 \\
\hline $\begin{array}{l}\text { Average purchase } \\
\text { intention }\end{array}$ & 2.63 & 3.83 & 3.71 & 3.62 & 3.50 & 3.62 & 3.39 \\
\hline
\end{tabular}

To test H4, we fit (model 4) ${ }^{4}$ with X (PP vs. CP), Y (purchase intention), and mediators $\mathrm{M}_{1,2}\left(\mathrm{M}_{1}=\right.$ transparency; $\mathrm{M}_{2}=$ recalled prices), and then compare the direct effects of $\mathrm{X}$ on $\mathrm{M}_{1,2}$. The coefficients are $0.1833\left(\mathrm{SE}=0.1429 ; \mathrm{M}_{1}\right)$ and $1.9955\left(\mathrm{SE}=0.5422 ; \mathrm{M}_{1}\right)$, so their difference is significant $(\mathrm{t}=-3.23 ; p<0.01)$, meaning that the effect of price format on recalled prices is stronger than on transparency, contrary to H4. Moreover, recalled prices (and not transparency) mediate the relationship between price format and purchase intention (coeff. $=-0.0843$; BootSE $=0,0334$, BootLLCI $=-0.2255$; BootULCI $=-0.0014)$. It seems that the lack of an explicit justification of the price difference (just the Fairtrade International label was visible) is insufficient to stop consumers from processing the price; on the contrary, they do process the price, which ultimately

\footnotetext{
${ }^{4}$ Recalled prices correlate with neither fairness ( $p=0.775$; corr. $=-0.017)$ nor transparency $(p=0.807$; corr. $=0.014)$.
}

(slightly) reduces the total (positive) effect of price format on purchase intention.

\section{Add-on: Boundary Conditions}

We tested several boundary conditions of $\mathrm{H} 1$ using analyses of variance (ANOVAs) that controlled for the main effect of the moderator in question and focused on the interaction with the price format of the fair-trade product (see Table 1): arithmetic and magnitude of the price component, product category, and fair-trade purchase frequency (merged into three buyer groups: low/occasional/frequent). None of them significantly interacts with purchase intention $(p s>0.05)$, so that the main effect (H1) is valid across these conditions. ${ }^{5}$

\footnotetext{
${ }^{5}$ Nevertheless, we recommend caution in interpreting these results, due to the relatively small cell sizes with respect to buyer group in the $\mathrm{CP}$ condition: 25 nonbuyers/11 occasional buyers/5 frequent buyers.
} 


\section{Concluding Remarks}

Two features of study 1 were fixed: First, the connection between the two products was implicitly indicated by the Fairtrade International logo attached to the fair-trade product with no reinforcing benefit communication, and second, the price format varied only for the fair-trade product. Studies 2 and 3 relax these assumptions and thus generalize the findings obtained thus far. Study 2 also disentangles the effect of price format from the effect of (the so far only implicit) benefit communication.

\section{Pretest for Studies 2 and 3}

We designed the pretest with a new manipulation check, directly asked after the manipulation, as many participants in study 1 had failed. Moreover, we included a multi-item measure for purchase intention. Because we are interested in consumers' attribution of the fair-trade price component, we included a measure to investigate consumers' perceived benefit of the fair-trade price component (Hamilton \& Srivastava, 2008). We tested two benefits communicated as fairtrade price components: (1) fair wages paid to developing country farmers and (2) worker and farmer well-being in developing countries (Darian et al., 2015; Didier \& Lucie, 2008; Stratton \& Werner, 2013).

To investigate whether the magnitude of the price component influences the perceived benefit of the fair-trade product based on the communicated benefit, we included it in the pretest. This resulted in $20 \%$ and $43 \%$ magnitude of the price component (43\% instead of $40 \%$ to avoid price ending effects, as in study 1). Hence, this pretest uses the following manipulations: conventional chocolate $(2.49 €)$ versus fairtrade chocolate $(2.99 €)$, with a fair-trade price component of either $0.50 €$ or $0.90 €$. This time, participants could choose between milk chocolate and dark chocolate.

\section{Sample Description}

The final sample consisted of 403 European participants. ${ }^{6}$ All prices were stated in euros, for consistency with the participants' nationality. The average age was 32 years, $57.3 \%$ were male; $46.7 \%$ had a disposable income between $\$ 20,000$ and $\$ 60,000,37.5 \%$ below $\$ 20,000$, and $8.7 \%$ above $\$ 60,000$, comparable to the descriptive statistics in the main studies. Table 3 gives an overview about the cell sizes in the respective manipulations.

\footnotetext{
$627.8 \%$ Portuguese, $22.6 \%$ Polish, $18.1 \%$ Italian, and the rest below $10 \%$ each.
}

Table 3 Pretest: Cell sizes and manipulations

\begin{tabular}{llll}
\hline $\begin{array}{l}\text { Benefit com- } \\
\text { munication } \\
(\mathrm{PP})\end{array}$ & Low magnitude & High magnitude & $\begin{array}{l}\text { Combined } \\
\text { Pricing }(\mathrm{CP})\end{array}$ \\
\hline Benefit 1 (PP) & $82[81]$ & $81[77]$ & 82 \\
Benefit 2 (PP) & $80[77]$ & $78[76]$ & \\
\hline
\end{tabular}

Cell sizes exclude participants who failed the manipulation check

\section{Results}

This time, only 10 participants failed the manipulation check, resulting in 311 eligible participants in the PP conditions (instead of 321) for the following analysis. Hence, we deem the manipulation successful.

First, using an ANOVA, we observe no main effects or interaction for either the different benefit communications or the magnitude of the price component on the perceived benefit, $(p s>0.05$ ), indicating that the two benefit communications were perceived as similar. Second, participants could choose their preferred chocolate, and $61.6 \%$ favored milk chocolate over dark chocolate. This might create demand effects, but as we are not interested in absolute levels of purchase intention but rather its increases due to the price format, this preference should not bias our hypothesis testing. Moreover, in the following studies, all participants evaluated milk chocolate (the majority's preference), which reduces these demand effects. The proportion of participants choosing milk chocolate is similar (CP: $62.2 \%$ and PP: $61.4 \%$; $\left.\chi^{2}=0.897\right)$ and hence do not need to be further considered.

\section{Concluding Remarks}

The results show that the manipulation works successfully. Participants recognized the fair-trade products' price format correctly. Moreover, the multi-item scale for purchase intention worked properly $(\alpha=0.919)$. Finally, the attribution of the fair-trade price component as a benefit works independently of the communicated justification for the price difference and does not vary with the magnitude of the price component. As the justification "Fair wages paid to farmers in developing countries" is more in line with the definition of PP, we use it for the next studies.

\section{Study 2: Disentangling the Effect of Price Format from the Explicit Benefit Communication}

Study 2 is the only one that independently varies the price format for both the fair-trade and conventional products, resulting in a $2 \times 2$ between-subjects design (scenarios $1,2,5$, 
Table 4 Study 2: scenarios, cell sizes, and average purchase intention

\begin{tabular}{llllll}
\hline Scenario & Conventional product & Fair-trade product & Condition & $\begin{array}{l}\text { Average pur- } \\
\text { chase intention }\end{array}$ \\
\hline 1 & 2.49 & 2.99 & CP-CP & 3.70 & 41 \\
2 & 2.49 & $2.49+0.50$ & CP-PP (FT) & 4.59 & 41 \\
3 & 2.49 & $2.49+0.50$ & CP-PP (Tax) & 3.33 & 40 \\
4 & 2.49 & $1.99+0.50+0.50$ & CP-PP (Tax +FT) & 4.91 & 40 \\
5 & $1.99+0.50$ & 2.99 & PP (Tax)-CP & 3.83 & 37 \\
6 & $1.99+0.50$ & $2.49+0.50$ & PP (Tax)-PP (FT) & 4.80 & 40 \\
7 & $1.99+0.50$ & $2.49+0.50$ & PP (Tax)-PP (Tax) & 3.18 & 39 \\
8 & $1.99+0.50$ & $1.99+0.50+0.50$ & PP (Tax)-PP (Tax +FT) & 4.96 & 42 \\
\hline
\end{tabular}

and 6; see Table 4 below). As the conventional product by definition has no fair-trade attribute, we use a tax-related price component. However, because this component is cost rather than benefit related, we extend this type of price component to the fair-trade product, leading to three PP conditions for the latter (tax, fair-trade, or tax + fair-trade; additional scenarios 3,4,7, and 8). In line with prestudy findings, participants saw an explicit justification of the fair-trade price component.

As in study 1, price format did not interact with product category in shaping purchase intention. Moreover, neither the arithmetic nor the magnitude of the price component influenced the core variables in study 1 , so we hold them constant here $(€ ; 17 \%)$. The price of chocolate is the same as in study 1 (fair-trade: $€ 2.99$; conventional: $€ 2.49$ ), exhibiting the same price difference (20\%). These specifications led to eight conditions: 2 (price format conventional product) $\times(1$ [price format of fair-trade product $=\mathrm{CP}]+3$ [price format of fair-trade product $=\mathrm{PP}]$ ).

\section{Sample Description}

The final sample consisted of 320 European participants. ${ }^{7}$ All prices were stated in euros. The average age was 27 years and $60 \%$ were male; $49.7 \%$ had a disposable income between $\$ 20,000$ and $\$ 60,000,34.4 \%$ below $\$ 20,000$, and $8.1 \%$ above $\$ 60,000$. $24.7 \%$ described themselves as non-fair-trade buyers, $62.2 \%$ as occasional fair-trade buyers, and $13.2 \%$ as frequent fair-trade buyers, although $72.5 \%$ of the participants indicated that they never or sometimes purchase fair-trade chocolate. Most participants indicated that they were somewhat or very familiar with the chosen product category $(84.7 \%)$ and its prices $(39.7 \%$, including moderately familiar $85.6 \%$ ). The mean fair-trade knowledge was 5.36 and the mean fair-trade attitude was 5.29 , both on 7-point Likert scales.

\footnotetext{
7 Nationality distribution was diverse: $29.1 \%$ Polish, $18.8 \%$ Portuguese, $9.4 \%$ Italian, and all others less.
}

\section{Results}

We performed an additional manipulation check with an ANOVA based on the theoretical considerations regarding attribution theory. Perceived benefit is similar $(p=0.34$, Bonferroni tests) for $\mathrm{PP}=$ fair - trade only (4.55) and $\mathrm{PP}=\operatorname{tax}+$ fair trade (4.75), and higher than $\mathrm{PP}=$ tax only (3.92) $(p s<0.01)$. Hence, participants considered the fairtrade price component, independent of whether tax was explicitly stated, as more beneficial than the "tax only" price component, as expected.

As in study 1, a test of balance indicates that the control variables did not differ across the manipulations (all $p$-values for the respective interaction with the manipulation are between $p=0.102$ (fair-trade knowledge) and $p=0.939$ (age). Hence, we do not include them in the hypothesis tests.

To test H1, we used an ANOVA with price formats (of the conventional and the fair-trade products) and their interaction to investigate effects on purchase intention (see Table 4). The results support H1 $(\mathrm{F}=18.824, p<0.01)$, while neither the price format of the conventional alternative $(\mathrm{F}=0.111, p=0.739)$ nor its interaction with the fair-trade format $(\mathrm{F}=0.188, p=0.905)$ impacts purchase intention. These results extend the stability of the hypothesized main effect. $^{8}$

Moreover, post hoc Bonferroni test shows that under PP for fair-trade $=\mathrm{CP}$, purchase intention is significantly lower (3.76) than under PP for fair-trade $=$ fair - trade resp. tax + fair- trade (4.69 resp. 4.93; $p$ s $<0.01)$. The two latter means (not different, $p=1$ ) are higher than under PP for fairtrade $=\operatorname{tax}(3.26, p s<0.01)$. Last, the price format for the fair-trade product $\mathrm{CP}$ (3.76) does not significantly vary from PP (tax, 3.26), $p=0.318 .{ }^{9}$ We further found that the price

\footnotetext{
8 The bipolar purchase intention scale confirms this as well: $\mathrm{H} 1$ is supported $(\mathrm{F}=15.663, p<0.01)$, while neither the price format of the conventional alternative $(\mathrm{F}=0.09, p=0.765)$ nor its interaction with the fair-trade format $(\mathrm{F}=1.149, p=0.33)$ impacts purchase intention.

${ }^{9}$ An additional post hoc Bonferroni test supports these results for the single item bipolar purchase intention scale.
} 
format (CP vs. PP) does not interact with the buyer group (no significant interaction with purchase intention; $p>0.05$ ).

\section{Concluding Remarks}

In studies 1 and 2, we held the price difference between the two products constant (20\%) although in practice, these differences vary by category (Fair-Trade Foundation, 2021e). Therefore, the question arises whether using PP (instead of $\mathrm{CP}$ ) for the fair-trade product is equally effective at various price differences. Is there a (category-specific) threshold beyond which adapting the price format from CP to PP no longer increases the purchase intention towards the fair-trade product? And are there (perhaps category-specific) thresholds below which consumers maintain a preference (i.e., purchase intention around or above the scale mean of 4) for the fair-trade product?

\section{Study 3: Explicitly Communicated Benefit and Increasing Price Differences}

To explore these potential threshold effects, we use five price differences (at equidistant points between 10 and $50 \%$ ) that are equivalent to the magnitude of the fair-trade price component (study 1 did not reveal an effect of the latter; therefore, it is held constant here). Given the range of price differences, it is impossible to avoid a threshold effect when comparing the conventional and fair-trade products (the euro amount before the decimal point will necessarily differ). However, we specified the total prices such that there is no threshold within the fair-trade prices: they are between $€ 2.19$ (10\% difference to $€ 1.99$, the price of the conventional product) and $€ 2.99$ (50\% difference), so in all cases above 2 and under 3 euros. As the thresholds might be categoryspecific, we again use chocolate and banana as products. Study 2 did not reveal any effect of the price format of the conventional alternative, so we use $\mathrm{CP}$ in all conditions. The core variable (price format of the fair-trade product) again varies between $\mathrm{CP}$ and $\mathrm{PP}$, while $\mathrm{PP}$ is combined with the benefit communication that emerged in the pretest and employed in study 2 . In summary, we have 20 conditions: 2 (products) $\times 2$ (price format of fair-trade product) $\times 5$ (price difference conventional vs. fair-trade).

\section{Sample Description}

The final sample consisted of 801 European participants. ${ }^{10}$ All prices were stated in euros for consistency with the

$1034.8 \%$ Polish, $18.2 \%$ Portuguese, $12.7 \%$ Italian, and the rest below $10 \%$ each. participants' nationality. The average age was 25 years, $62.4 \%$ were male; $41.5 \%$ had a disposable income between $\$ 20,000$ and $\$ 60,000,43.7 \%$ below $\$ 20,000$, and $6.4 \%$ above $\$ 60,000$. In addition, $28.8 \%(57.6 \%, 13.6 \%)$ were non(occasional, frequent) fair-trade buyers. However, 75.3\% of the participants indicated that they never or sometimes purchase fair-trade chocolates/bananas. Most participants were very or extremely familiar with the chosen product category (78\%) and very or moderately familiar with its prices $(72.7 \%)$. The mean fair-trade knowledge was 5.34 and the mean fair-trade attitude was 5.12, both on 7-point Likert scales.

\section{Results}

Before testing the hypotheses, we checked the control variables for differences in means between the manipulations. All $p$-values (interaction between manipulation and control variable) were between $p=0.097$ (fair-trade knowledge; values ranged from 4.88 to 5.65 on a 7-point Likert scale) and $p=0.970$ (product purchase frequency); hence, we do not consider them in the hypothesis tests.

The total effect (model 6) of X (PP vs. CP) on Y (purchase intention) with mediators $\mathrm{M}_{1,2}\left(\mathrm{M}_{1}=\right.$ transparency; $\mathrm{M}_{2}=$ fairness $)$ is $0.6624(\mathrm{SE}=0.1109 ; t=5.9731 ; p<0.01)$. The direct effect is -0.0272 ( $\mathrm{SE}=0.0971 ; t=-0.2803 ; p=0.78)$, the indirect effect through $\mathrm{M}_{1}$ is 0.2814 (BootSE $=0.0509$; BootLLCI $=0.1858$; BootULCI $=0.3839$ ), the indirect effect through $\mathrm{M}_{2}$ is 0.1171 (BootSE $=0.0536$; BootLLCI $=0.0145$; BootULCI $=0.2255$ ), and the indirect effect through $\mathrm{M}_{1}$ and $\mathrm{M}_{2}$ is 0.2911 (BootSE $=0.0372$; BootLLCI $=0.2212$; BootULCI $=0.3691)$. These results support H1, H2, and $\mathrm{H} 3$. Table 5 gives an overview about this studies cell sizes, manipulations, and average values for purchase intention.

To test H4, we fit model $4^{11}$ with X (PP vs. CP), Y (purchase intention), and mediators $\mathrm{M}_{1,2}\left(\mathrm{M}_{1}=\right.$ transparency; $\mathrm{M}_{2}=$ recalled prices), and then compare the direct effects of $\mathrm{X}$ on $\mathrm{M}_{1,2}$. The coefficients are 1.0915 ( $\mathrm{SE}=0.0872$; $\left.\mathrm{M}_{1}\right)$ and $0.1014\left(\mathrm{SE}=0.0199 ; \mathrm{M}_{1}\right)$, so their difference is significant $(\mathrm{t}=11.07 ; p<0.01)$, in support of $\mathrm{H} 4$. The key difference from study 1 is the additional explanation of the fair-trade price component, reinforcing the benefit communication. The mediation through transparency (coeff. $=0.5717$, BootSE $=0.0655$, BootLLCI $=0.4458$, BootULCI $=0.7020$ ) but not recalled prices is significant this time, probably due to the added explanation. Studies 1 and 3 taken together therefore show that either transparency or recalled prices

\footnotetext{
$\overline{11}$ Recalled prices correlate with neither fairness $(p=0.586$; corr. $=-0.019)$ nor transparency $(p=0.222$; corr. $=-0.043)$.
} 
Table 5 Study 3: scenarios, cell sizes, and average purchase intention

\begin{tabular}{lllllll}
\hline Product & $\begin{array}{l}\text { Price differ- } \\
\text { ence (in \%) }\end{array}$ & $\mathrm{N}(\mathrm{CP})$ & $\mathrm{N}(\mathrm{PP})$ & $\begin{array}{l}\text { Average purchase } \\
\text { intention }(\mathrm{CP})\end{array}$ & $\begin{array}{l}\text { Average purchase } \\
\text { intention (PP) }\end{array}$ & $\begin{array}{l}\text { Delta } \\
\text { purchase } \\
\text { intention }\end{array}$ \\
\hline Chocolate & 10 & 41 & 39 & 3.87 & 5.24 & 1.37 \\
& 20 & 41 & 40 & 4.09 & 4.80 & 0.71 \\
& 30 & 40 & 40 & 3.36 & 4.12 & 0.76 \\
& 40 & 39 & 40 & 3.70 & 4.13 & 0.43 \\
& 50 & 40 & 40 & 3.46 & 3.94 & 0.48 \\
Banana & 10 & 39 & 41 & 4.45 & 4.78 & 0.33 \\
& 20 & 40 & 40 & 4.39 & 4.82 & 0.43 \\
& 30 & 38 & 40 & 4.00 & 4.90 & 0.90 \\
& 40 & 41 & 41 & 4.00 & 4.34 & 0.43 \\
& 50 & 40 & 41 & 3.80 & 4.69 & 0.89 \\
\hline
\end{tabular}

(beyond fairness; $\mathrm{H} 2$ ) - depending on the implementation of the benefit communication-explain the main effect $(\mathrm{H} 1)$.

\section{Add-On: Boundary Conditions}

To assess possible boundary conditions, we again checked for various interactions with ANOVAs. First, although price difference impacts purchase intention directly (the bigger it gets, the lower purchase intention), it does not interact with the fair-trade price format $(p=0.633)$, product category $(p=0.318), n=$ or income $(p=0.945)$. Interestingly, even at price differences of $50 \%$, the average purchase intention is never significantly below 4 , the scale mean, in either product category (although it is on average higher for bananas than chocolates). Within the investigated range of price differences, therefore, we observed no "threshold" beyond which the pricing tactic (PP vs. $\mathrm{CP}$ ) would become ineffective. Moreover, for neither product category $(p=0.452)$ nor purchase frequency (merged into three "buyer groups"-no, occasional, frequent buyers; $p=0.776$ ), fair-trade price format interact in shaping purchase intention. Thus, similar to studies 1 and 2, we find no boundary conditions of the main effect or of the additional effect of price difference, which increases the stability and generalizability of the previous findings.

\section{Concluding Remarks}

Studies 1-3 involve hypothetical purchase intentions. Therefore, with the final empirical study, we seek to add external validity, using an incentive-aligned setting that combines the questionnaire with a potential purchase transaction.

\section{Study 4: Real Purchases to Test H1}

To reveal consumers' truthful answers and address the hypothetical bias of the attitude-behavior gap, we must observe actual behavior in an incentive-aligned approach (Andorfer \& Liebe, 2012; Doran, 2009; Johnstone \& Tan, 2015). Hence, study 4 uses an incentive-aligned setting with real choices (and as such a measure of revealed purchase intention), to determine whether $\mathrm{H} 1$ remains valid. As the additional transaction would take time and the previous studies did not reveal any substantial direct or moderating effects of control variables, we decided to focus on the manipulation and measurement of purchase intention (controlling only for age and gender).

For the sake of realism, we used the real (market) category-specific prices (conventional product: $€ 0.87$ for chocolate; $€ 1.15$ for banana) and real price differences between the two products ( $48 \%$ for chocolate and $9 \%$ for banana; both are within the range of manipulations in study 3 ). While the price format was $\mathrm{CP}$ for the conventional product, it varied for the fair-trade product, and within $\mathrm{PP}$, we used a combined variation of the arithmetic and the magnitude of the fair-trade price component (as a compromise between efficiency - the related results were nonsignificant in study 1 -and additional exploration of these factors). As in study 1 , the connection between price difference and benefit was only implicit, indicated by the Fairtrade International logo (i.e.,, no additional verbal explanation of the price difference, which created strict testing conditions as in study 1). 


\section{Method and Design}

We employed a stated choice set method to determine consumers' behavior (Louviere et al., 2000), a commonly used method in the nutrition literature and suitable for measuring preference for fair-trade products (Andorfer \& Liebe, 2012; Gracia, 2014) as participants would reveal their true preferences (Auger \& Devinney, 2007). A discrete choice experiment is based on choice sets containing two or more options (Street et al., 2005) that differ in their attribute levels (Gracia, 2014). The options (eight choice sets; see Table 1) and attributes differed only in relation to the price format of the fair-trade product.

Each participant evaluated all eight choice sets, composed of a direct comparison between the conventional product and one of the eight PP manipulations, and indicated their choice: conventional product, fair-trade product, or none of them (included to reduce the social desirability bias; Alfnes et al., 2006; Gracia, 2014).

They learned that afterward, a lottery would select one of the eight choice sets for each participant as binding and that they had to accept their choice within that set (Alfnes et al., 2006; Lusk \& Schroeder, 2004; Michaud et al., 2013; Yue \& Tong, 2009): If they indicated that they would be willing to buy a product, they were obliged to buy the chosen item, priced as in the binding choice set, with their own money. If they indicated the "none of them" option, no purchase was necessary. Therefore, it was in participants' interest to respond to each choice set according to their true preferences. After the experiment, all participants received a $5 €$ reward for their participation (Gracia, 2014).

\section{Sample Description}

We recruited 49 students at a European business school of varying nationalities. The average age was 22 years, and $49 \%$ were male. No participants refused to purchase the product they chose from the binding choice set at the given price if indicated.

\section{Results}

For chocolates (price difference of 48\%), participants indicated no preference for the fair-trade product. For both price formats of the fair-trade product (PP vs. CP), the choice rates were exactly the same: $51 \%$ of the participants indicated they would buy the conventional chocolate over the fair-trade chocolate, $37 \%$ wanted to buy the fair-trade chocolate, and $12 \%$ indicated they would not buy anything. Consequently, H1 cannot be confirmed for chocolate.

In contrast, the main effect does emerge for bananas (price difference of 9\%): The price format strongly influences the purchase intention. In the combined (partitioned) condition, $45 \%$ (24\%) indicated they would buy the conventional banana, 53\% (73\%) indicated they would buy the fair-trade banana, and 2\% (3\%) indicated they would not buy anything. Partitioning the fair-trade price increased participants' choice to buy that product by $20 \%$. Consequently, the price format (PP vs. CP) and choice interact; more specifically, the price format increases choice to buy the fair-trade product $\left(\chi^{2}=22.335, p<0.01\right)$, in support of $\mathrm{H} 1$.

\section{Discussion}

Study 4 finds support for H1 when considering revealed rather than stated intentions. However, this effect only emerges for fair-trade products with a comparatively small price difference when explicitly displayed with PP (price difference of $9 \%$ ), not with a high price difference (price difference of $48 \%$ ). For a small fair-trade price difference (9\%), purchases increased by $20 \%$. Thus, a boundary condition of the effect specified in H1 (i.e., the price difference) becomes relevant only when considering actual consumer behavior. As study 3 showed no interaction between price format and income on purchase intention, we deem these results as generalizable, although generated with a student sample. It seems plausible to infer that a maximum price difference (a threshold) exists at which consumers evaluate the fair-trade product more favorably, compared with the conventional alternative, under PP than under $\mathrm{CP}$ when considering actual choices. As social desirability issues and the associated answering patterns are common in ethical research, we included the "none of them" answer (Andorfer \& Liebe, 2012; Loureiro \& Lotade, 2005): participants indicated "none of them" 5 (24) times for banana (chocolate), which indicates that participants understood that it was a valid option and that they were not driven by socially desirable answering patterns.

Moreover, as participants only received the monetary reward after the participation, we infer that this experiment could be viewed as realistic. If participants indicated they wanted to buy a product, they would end up with less money than those who did not indicate they wanted to purchase anything. Moreover, participants had to pay for the respective product, if indicated, with their own money first before receiving any monetary reward for their participation.

\section{General Discussion}

\section{Summary of Results}

Our studies show that offering the fair-trade product under PP rather than CP increases consumers' purchase intention over the conventional alternative. Therefore, in line with Bertini and Wathieu (2010), PP can indeed highlight 
overlooked benefits. As such, a simple pricing mechanism (which is also a cost- and time-efficient marketing mix measure, compared with, e.g., communication measures) can help communicate a benefit to consumers and increase their purchase intention towards a more sustainable product.

This effect is valid and stable across various settings and conditions: independent of whether the fair-trade price component is justified explicitly for consumers with varying degrees of fair-trade knowledge, attitude, and purchase frequency (these characteristics may differ by country market); in different low-involvement product categories, branded and non-branded, for which price differences to conventional alternatives in practice vary quite substantially (chocolate: branded and high price difference; banana: non-branded and low price difference); across age, gender, country regions (study 1: American, studies 2 and 3: European), and income groups; in samples that are diverse in terms of nationalities (Studies 2-4); independent of the magnitude or the arithmetic of the fair-trade price component (study 1); independent of the price format of the conventional alternative (study 2 ); and independent of the price difference between the two products in a certain interval (up to 50\%) (study 3). The effect also emerges for real purchase decisions, showing external validity (study 4 ). The only boundary condition we observe is that the price difference between the two products should not be too high.

This main effect can be explained by increased perceptions of price fairness (studies 1 and 3). The additional mediation through transparency (confirmed in study 3 but not study 1) might be connected to the presence (study 3 ) versus absence (study 1) of an extra verbal justification of the fairtrade price component, a reason that also might explain the mixed findings regarding $\mathrm{H} 4$. $\mathrm{H} 4$ relates to the alternative explanation (recalled prices instead of transparency), and while transparency does emerge as the dominant explanation when the fair-trade price component is justified in more (verbal) detail (study 3), it is recalled prices that explain the positive effect (of PP on purchase intention) in the absence of such a justification (study 1).

The additional analyses related to potential moderating variables clearly show that few boundary conditions for the main effect (H1) exist. This might be viewed as somewhat surprising, given the numerous factors (in terms of buyer, situational, and price component characteristics) we used to represent the variety of potential moderators suggested in Voester et al.'s (2017) state-of-the-art review on PP. At the same time, this result makes the effect of PP all the more prominent, emphasizing its stability, generalizability, and practical applicability in the fair-trade context.

The only potential boundary condition is the price difference between fair-trade and conventional products. Studies 1 and 3 reveal no significant interaction with the price format in shaping consumers' purchase intentions. However, study 4 illustrates that with rather high price differences (connected to product category), PP does not increase the choice rate of the fair-trade product. In contrast, low price differences (banana $=9 \%$ ) increase the choice rate by $20 \%$ for the fair-trade product. Although study 3 does not identify any interactions of the main effect with income, it could be a potential reason for this boundary condition that emerges in actual consumer behavior.

\section{Implications}

\section{Managerial Implications}

The price differences for raw materials are globally determined by Fairtrade International; thus, if companies communicate the price difference they must pay with the help of PP, especially with an extra justification of the fair-trade price component, purchases can increase significantly. This could help reduce the attitude-behavior gap. In addition, the increase toward actually buying fair-trade products holds true even when the fair-trade product price (i.e., price difference minus the price component) is higher than the conventional product's price. This finding is especially important for producers that cannot compete on the base product price. Hence, PP could be a fast and easy-to-implement remedy.

Moreover, PP can increase sales and should thus be an attractive alternative to price promotions for retailers. As such, it represents a promising way for companies to increase sales for fair-trade products and nudge their customers into more ethical consumption. In this context, the implicit added value of fair-trade label can turn into explicit price communication, and retailers could use it as a unique selling proposition, possibly resulting in improved company perceptions as well.

Additionally, as this effect holds true for various customer segments (e.g., buyer groups with different purchase frequencies, nationalities), companies do not need to differentiate their pricing tactic: it will be beneficial regardless of their target customer segment.

As we could not detect any substantial threshold effect (study 3 ), even at a price difference of around $50 \%$, consumers prefer the fair-trade option with PP compared to CP, which means some pricing potential for fair-trade products exists, and the feasibility of higher prices could even help increase these products' ethicality and sustainability. Nevertheless, a precondition for this recommendation is a certain level of fair-trade acceptance within a consumer group. Although PP is beneficial in consumer groups with lower levels of fair-trade purchase frequency and knowledge (study 1) and in lower-income groups (study 4), those segments might still prefer the conventional alternative. Put differently, PP helps increase the market share for fair-trade products 
(relative success); whether this market share is larger than that of competing (conventional) products (absolute success) depends on additional factors such as consumers' attitudes towards fair-trade products and their related purchase behavior. In any case, PP helps mainstream supermarkets contribute to improved social welfare and sustainability.

\section{Theoretical Implications}

This study complements research on ethical consumption by adding price format to the list of variables that foster preferences for fair-trade products (De Pelsmacker \& Janssens, 2007) and by adding the fair-trade context to the PP literature (Voester et al., 2017). We follow Voester et al. and's (2017, p. 905) call "to examine the causal chain from PP through price transparency and price fairness to offer evaluations" and further show that the positive effect of PP on purchase intention (Xia \& Monroe, 2004) can be transferred to premium products and actual consumer behavior.

Interestingly, although Voester et al. (2017) suggests many moderating variables for the positive/negative influence of price format on consumer behavior, we find that it is likewise possible that the effect of PP is not influenced positively or negatively by any of them. More specifically, $\mathrm{PP}$ in our context is always beneficial, regardless of factors that typically negatively interact with price format, such as magnitude (high) or arithmetic (raw units) of the price component (Bambauer-Sachse \& Mangold, 2010; Kim, 2006; Sheng et al., 2007; Xia et al., 2004). This might be due to the benefit- (instead of cost-) related price component, in line with our theoretical considerations regarding attribution theory. Additionally, this reflects the more recently debated contradictory (and therefore context-specific) impact of PP: about 52\% (48\%) of all studies show positive (negative) effects of PP vs. CP on consumer behavior (Abraham \& Hamilton, 2018).

Altogether, if PP is applied to the context of fair-trade pricing, we tentatively conclude that its effect (on purchase intentions) is simplified (i.e., does not vary by buyer characteristics, situational variables, or price component specificities) and is therefore straightforward and stable.

\section{Limitations and Future Research Directions}

This study has some limitations that point to promising avenues for future research. First, we included only one study with real purchases with a potentially limited sample (i.e., students). A field test could increase external validity. Additionally, as the price differences vary by product category (study 4), various price differences should likewise be tested more systematically, particularly in a broader field test.
Second, although we did include several additional variables (controls and moderators), this list could be extended to further increase our findings' generalizability. We suggest investigating the following:

\section{(1) Product characteristics:}

(a) Branding effects A brand represents another benefit-related attribute that can cause relative evaluation to vary between both products (depending on whether any of the products are branded). As the main effect relates to a change in purchase intention due to the price format, we expect that additional benefit-related attributes do not affect this change; nevertheless, this should be investigated.

(b) Product story As study 4 (actual behavior) illustrates, a possible boundary condition of the price format effect could be the price difference between a fair-trade product and its conventional alternative. However, this (or income) might not be the only explanation for this possible boundary condition. In this respect, it would be interesting to further investigate reasons related to the product category itself. For example, do fair-trade chocolate and bananas evoke or associate with differently strong fair-trade "stories" because their production processes are not equally complex and therefore require more or fewer people (who will then benefit from fairer pricing)?

(2) Seller characteristics Trust is important in buyer-seller relationships (Doney \& Cannon, 1997). Is trust (e.g., in green products; Johnstone and Tan (2015), in the company [Campbell et al., 2015]) a boundary condition for the believability of the displayed fair-trade price component? How can trust be positively influenced with additional marketing activities?

(3) Additional situational characteristics This research focused on low-involvement dairy products. It would be interesting to investigate if the same increase in purchase intention emerges for high-involvement products. The results might differ (Holmes \& Crocker, 1987), although social attributes of a product are important to both product types (Auger et al., 2010).

(4) Additional buyer characteristics Our samples intentionally included subjects from different regions (U.S. and Europe) to account for presumably different levels of fair-trade prevalence and acceptance. Therefore, a more systematic investigation could shed light on potential cross-cultural differences and therefore offer more nuanced implications, for example, for international marketing managers. 
Third, we conducted a point-in-time analysis that ignored retailers' action parameters. To extend the list of practical recommendations and provide more differentiated guidance for practical implementation of our suggested pricing tactic, we recommend the following additional studies:

(1) Long-term effects and conditions Does consumer purchase behavior change consistently, or do other factors hinder permanent change in consumer behavior? For example, can fair-trade price components be so low that consumers start suspecting some form of greenwashing? Or can fair-trade price components be so high that consumers infer a lack of quality (such that they perceive the product price itself [i.e., excluding the fairtrade component] as comparatively low)?

(2) Additional practical aspects such as aisle management of pricing policies Aisle management can have a strong impact on consumer behavior and product choice (Basuroy et al., 2001; Bezawada et al., 2009; Dhar et al., 2001; Page et al., 2019; van Herpen et al., 2012). Depending on a supermarket's aisle management (or price display restrictions), different effects for selling fair-trade products might emerge if products are placed in designated fair-trade product aisles only or between conventional products, creating the situation we refer to in this study. Does PP differ depending on aisle management decisions?

(3) Additional practical aspects such as greenwashing Companies are increasingly using their activities (Nyilasy et al., 2014) to intentionally mislead consumers regarding environmental benefits and performance (i.e., greenwashing) (Dahl, 2010; Delmas \& Burbano,
2011; Nyilasy et al., 2014), typically aiming to benefit from a green image and consumers' subsequent positive reactions (Delmas \& Burbano, 2011). Advertising is the most prominent way to communicate CSR activities (Chen \& Chang, 2013; Nyilasy et al., 2014), and an increasing number of eco labels adds to consumers' mistrust (Langer et al., 2008). Even for companies that are honestly engaging in CSR, the benefits of CSR communication may be perceived as questionable (Parguel et al., 2011). As such, it is possible that consumers may perceive fair-trade as greenwashing if they are not aware of its benefit (i.e., they do not know the proportion of the products price that benefits fair-trade, if they are displayed with CP). Displaying fair-trade prices with PP to increase their attractiveness could also subsequently increase a company's reputation because its price communication may be perceived as more trustworthy (Castaldo et al., 2009). This, in turn, can lead to a reduced hazard of being accused of greenwashing. This line of thought could also be transferred to other CSR areas such as socially responsible investments (Døskeland \& Pedersen, 2016).

In conclusion, we find that PP is a promising tool to increase the popularity of fair-trade products. We hope that the resulting practical recommendations will be applied to promote sustainability.

\section{Appendix 1}




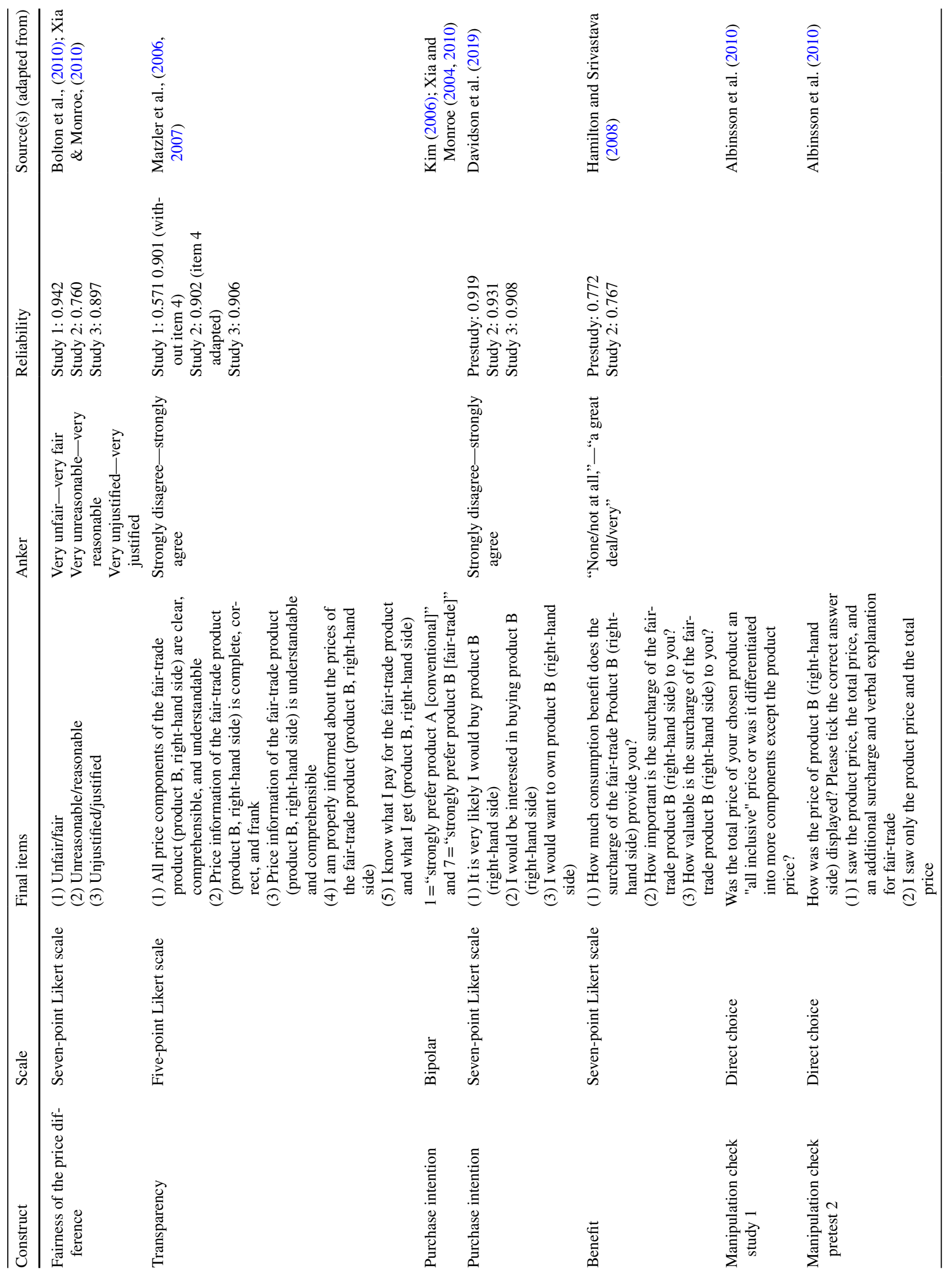




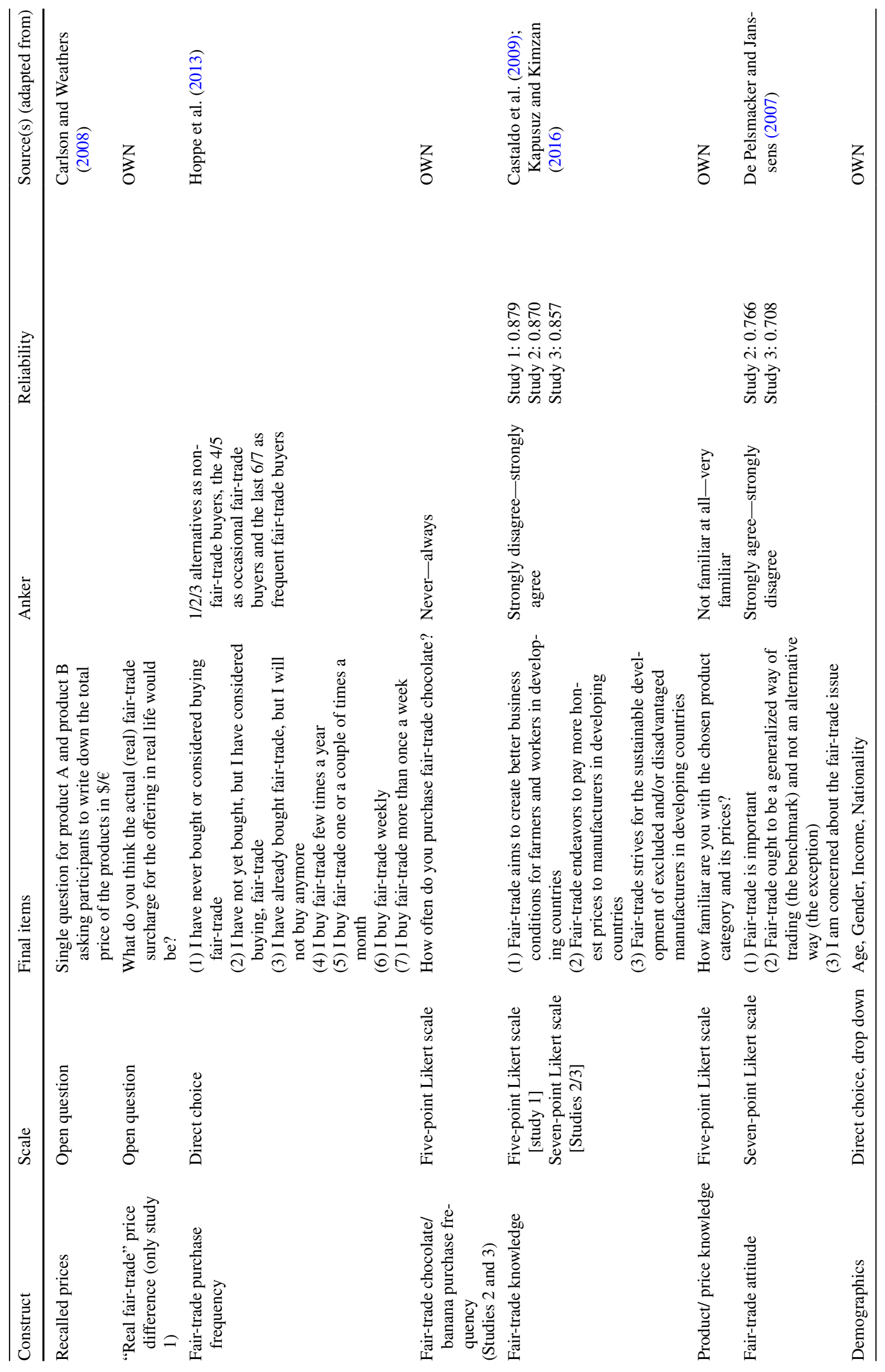




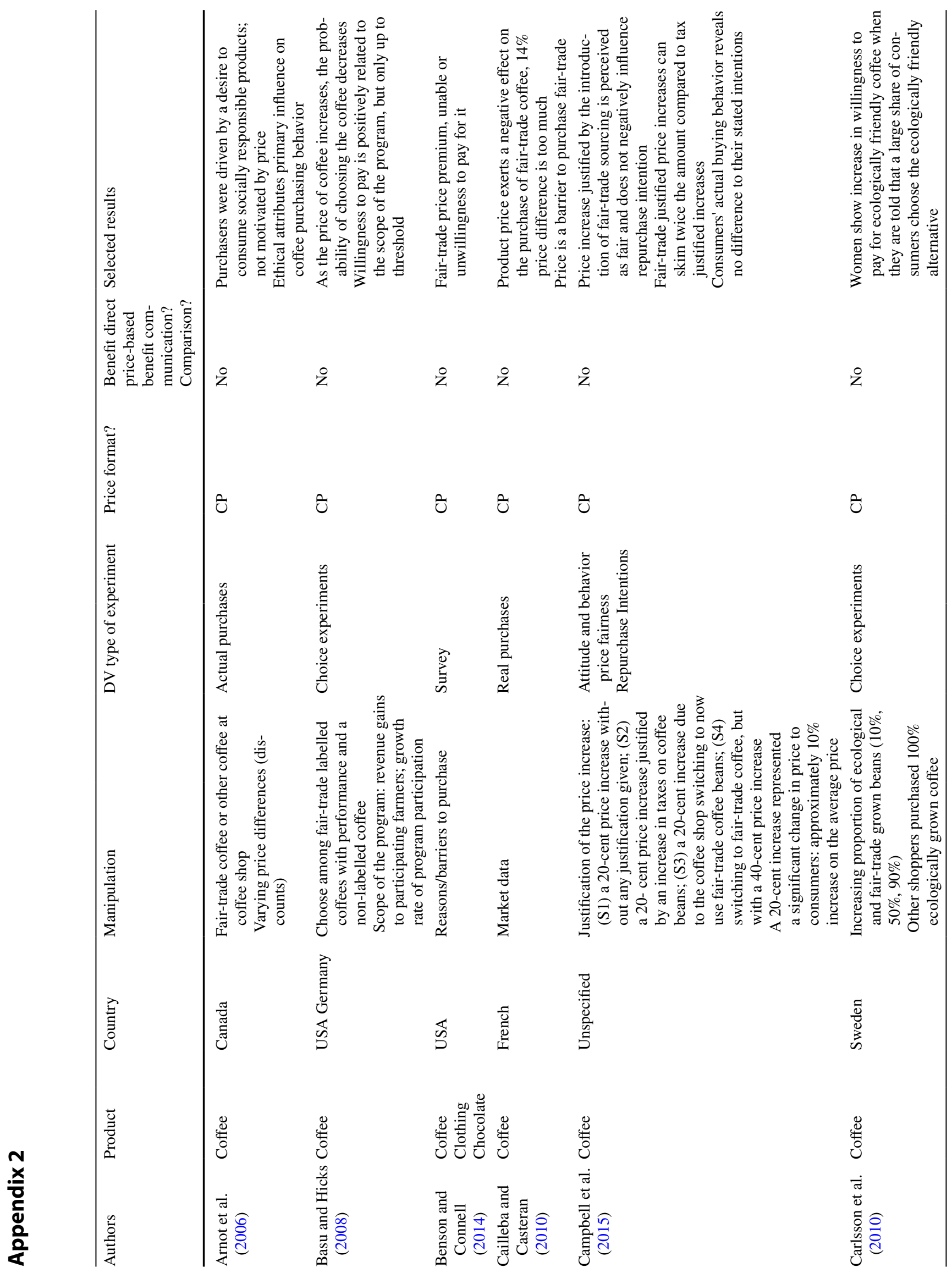




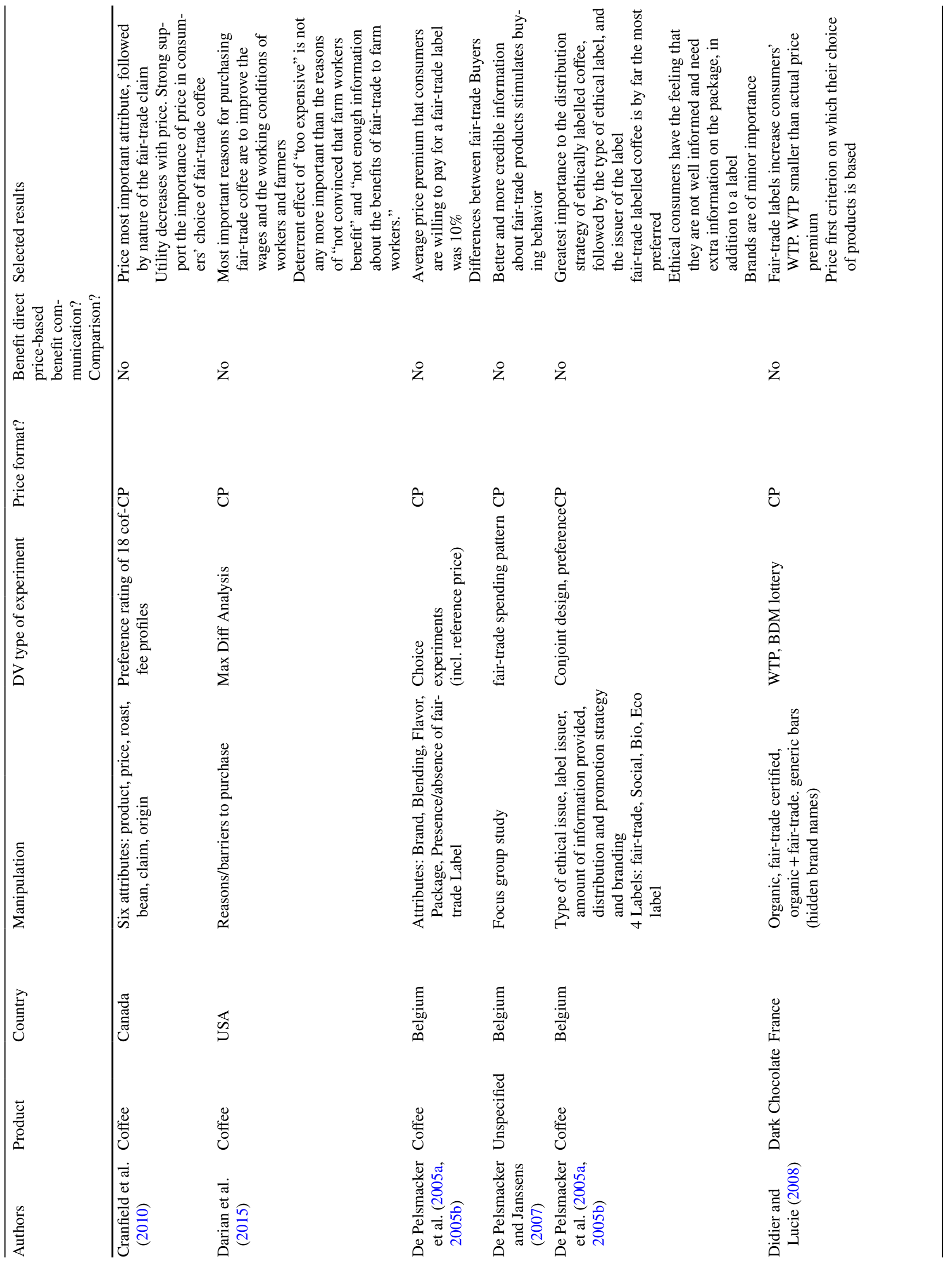




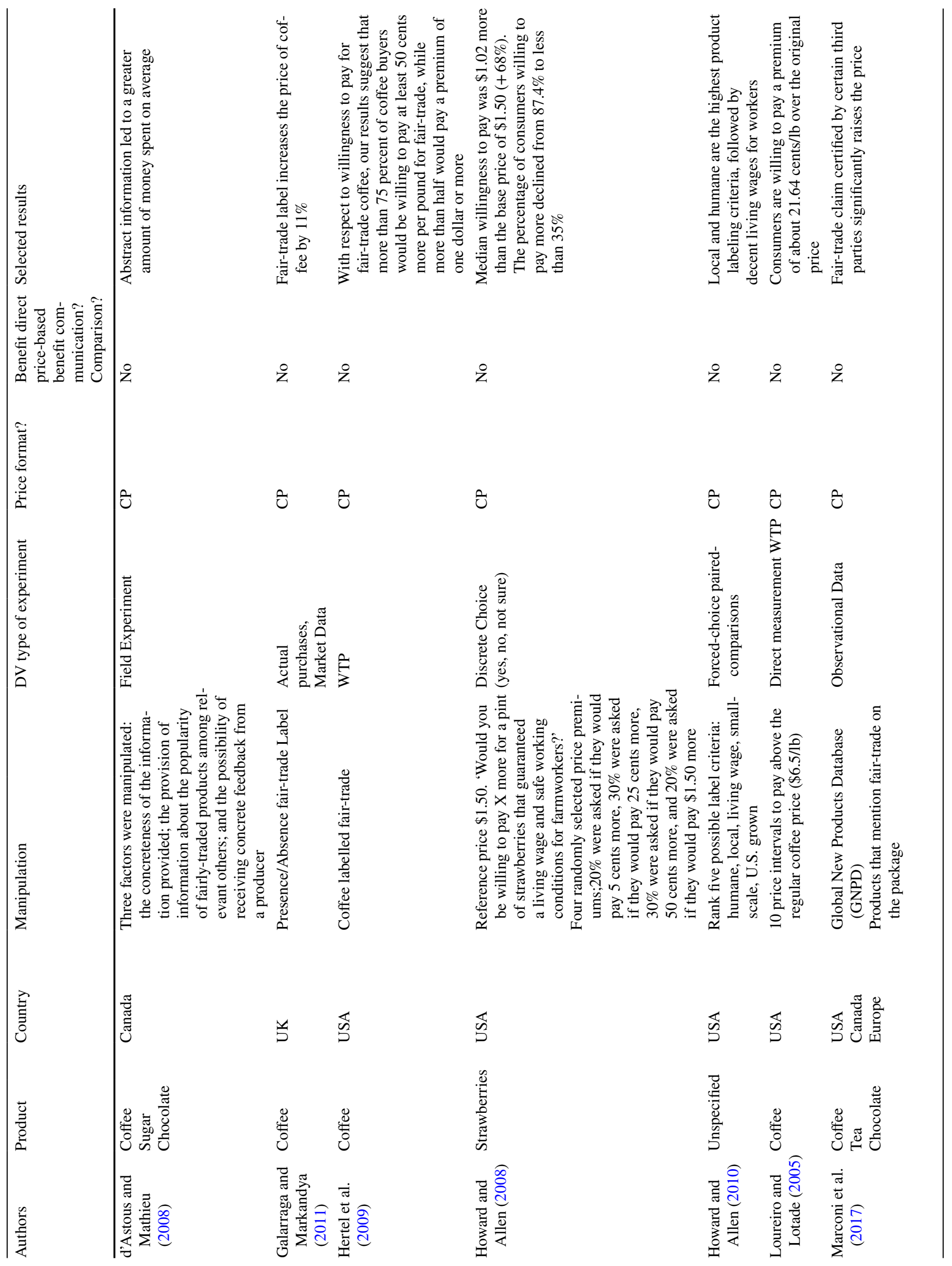




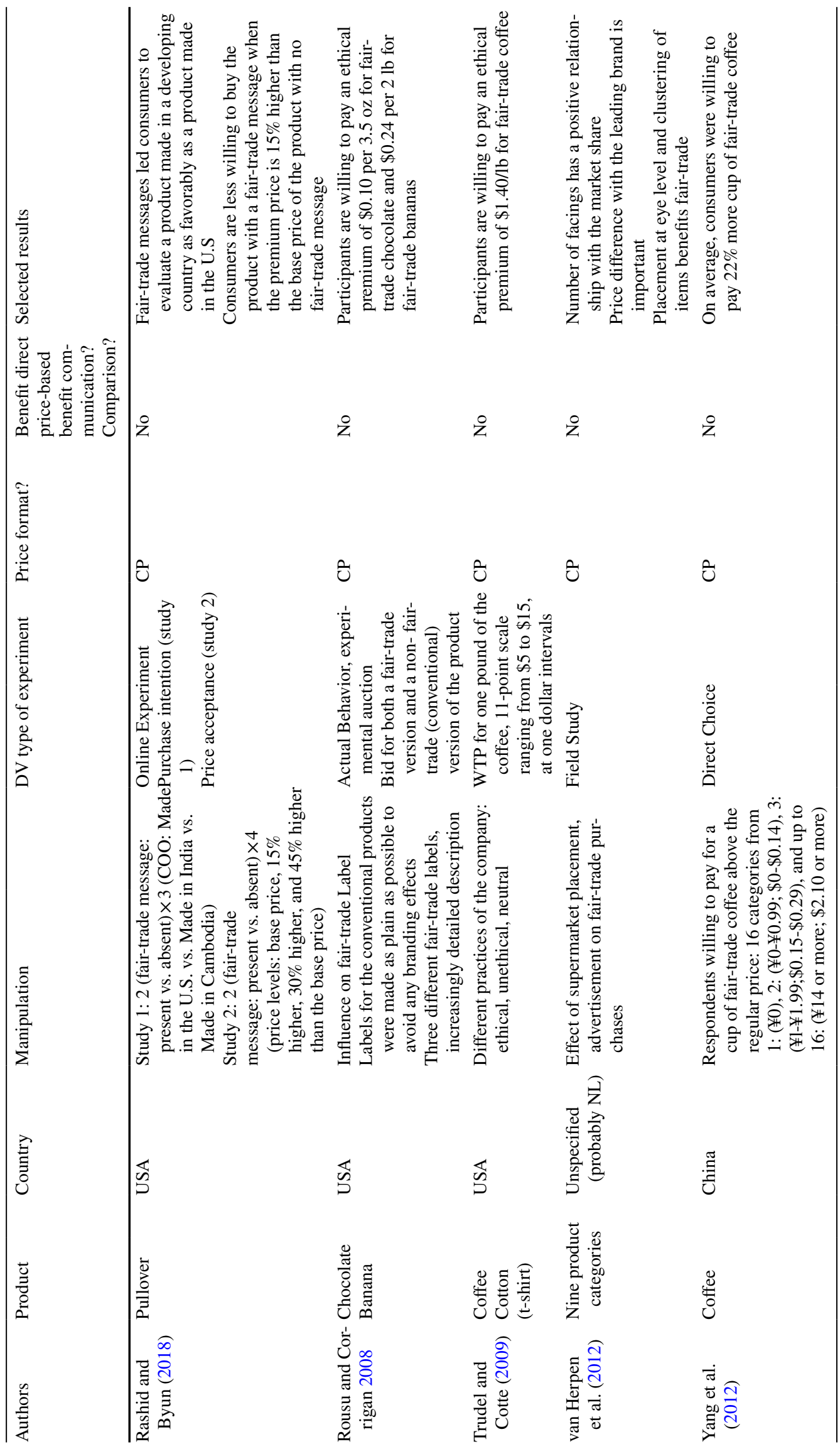


Funding Open Access funding enabled and organized by Projekt DEAL. This study was funded by ESCP Business School's internal program called 'European Research Funding'. Project applications can be submitted to the European Research Committee (on an annual basis), which then prepares recommendations on which projects to be funded, and to what extent, to the Executive Board of the school.

\section{Declarations}

Conflict of interest The authors have no relevant financial or non-financial interests to disclose. The authors have no conflicts of interest to declare that are relevant to the content of this article. All authors certify that they have no affiliations with or involvement in any organization or entity with any financial interest or non-financial interest in the subject matter or materials discussed in this manuscript. The authors have no financial or proprietary interests in any material discussed in this article.

Research Involving Human Participants and/or Animals The study setup was submitted to the ESCP's European Research Committee, and the decision communicated to the authors by the Associate Dean of Research, Professor P. Bunkanwanicha, said that " $[t]$ he research methods described in the application comply with ethical standards and can be applied as described." [Date of communication: January 27, 2020; letter available from the authors upon request].

Informed Consent Studies 1-3: We recruited participants through the panel provider "Prolific," specifying the citizenship "U.S. American" [study 1], "European" [studies 2 and 3 including the pretest] to the provider. Members of this panel decide on their own whether or not to participate in any study offered to them. Consequently, participation in this study was voluntary. When panel members do decide to participate, they receive a monetary incentive (normally $1.25 £$ per $10 \mathrm{~min}$ and increasing on the survey's length). Study 4: Participants were students and recruited at the Business School where the authors are employed. The study had no connection to any class and was organized as a separate, voluntary event. We announced, personally and through the student management system, that a study would take place and that anyone interested in participating in the study, which would be used for a scientific article, could voluntarily participate, receiving a monetary reward for their participation. Before conducting the study, we informed the participating students that we are interested in their choices for various products (asked for in eight choice sets), and that after the survey, a lottery would determine one of these choice sets as binding, so that they would have to act accordingly (in particular, pay the price stated in the choice set in exchange for the product in question). We explained that if they were not interested in risking to be obliged to buy any given product as an outcome of the lottery, it would be in their interest to not choose such products in the survey (i.e., in the eight choice sets). After conducting the study, participants signed for participation and received the announced monetary reward. When we communicated the outcome of the lottery, no participant 'refused to purchase the product they chose from the binding choice set at the given price' (see "sample description" in section "Study 4: Real purchases to test H1"). In summary, informed consent was obtained from all individual participants included in the study.

Open Access This article is licensed under a Creative Commons Attribution 4.0 International License, which permits use, sharing, adaptation, distribution and reproduction in any medium or format, as long as you give appropriate credit to the original author(s) and the source, provide a link to the Creative Commons licence, and indicate if changes were made. The images or other third party material in this article are included in the article's Creative Commons licence, unless indicated otherwise in a credit line to the material. If material is not included in the article's Creative Commons licence and your intended use is not permitted by statutory regulation or exceeds the permitted use, you will need to obtain permission directly from the copyright holder. To view a copy of this licence, visit http://creativecommons.org/licenses/by/4.0/.

\section{References}

Abraham, A. T., \& Hamilton, R. W. (2018). When does partitioned pricing lead to more favorable consumer preferences? Meta-analytic evidence. Journal of Marketing Research, 55(5), 686-703. https://doi.org/10.1177/0022243718800724

Albinsson, P., Burman, B., \& Das, N. (2010). Price surcharge and the effects of construal level. Journal of Applied Business and Economics, 11(4), 56-69.

Alfnes, F., Guttormsen, A. G., Steine, G., \& Kolstad, K. (2006). Consumers' willingness-to-pay for the color of salmon: A choice experiment with real economic incentives. American Journal of Agricultural Economics, 88(4), 1050-1061. https://doi.org/10. $1111 / \mathrm{j} .1467-8276.2006 .00915 . x$

Allard, T., \& Griffin, D. (2017). Comparative price and the design of effective product communications. Journal of Marketing, 81(5), 16-29. https://doi.org/10.1509/jm.16.0018

Anderson, E. T., \& Simester, D. I. (2003). Effects of \$9 price endings on retail sales: Evidence from field experiments. Quantitative Marketing and Economics, 1(1), 93-110. https://doi.org/10. 1023/A:1023581927405

Andorfer, V. A., \& Liebe, U. (2012). Research on fair-trade consumption-A review. Journal of Business Ethics, 106(4), 415-435. https://doi.org/10.1007/s10551-011-1008-5

Arnot, C., Boxall, P. C., \& Cash, S. B. (2006). Do ethical consumers care about price? A revealed preference analysis of fair trade coffee purchases. Canadian Journal of Agricultural Economics/ revue Canadienne D'agroeconomie, 54(4), 555-565. https://doi. org/10.1111/j.1744-7976.2006.00066.x

Auger, P., \& Devinney, T. M. (2007). Do what consumers say matter? The misalignment of preferences with unconstrained ethical intentions. Journal of Business Ethics, 76(4), 361-383. https:// doi.org/10.1007/s10551-006-9287-y

Auger, P., Devinney, T. M., Louviere, J. J., \& Burke, P. F. (2010). The importance of social product attributes in consumer purchasing decisions: A multi-country comparative study. International Business Review, 19(2), 140-159. https://doi.org/10.1016/j.ibusr ev.2009.10.002

Bambauer, S., \& Gierl, H. (2008). Should marketers use price partitioning or total prices? Advances in Consumer Research, 35, 262-268.

Bambauer-Sachse, S., \& Mangold, S. (2010). Does a marketer $s$ responsibility for a surcharge moderate price partitioning effects? Advances in Consumer Research, 37, 333-340.

Basu, A. K., \& Hicks, R. L. (2008). Label performance and the willingness-to-pay for Fair-Trade coffee: A cross-national perspective. International Journal of Consumer Studies, 32(5), 470-478. https://doi.org/10.1111/j.1470-6431.2008.00715.x

Basuroy, S., Mantrala, M. K., \& Walters, R. G. (2001). The impact of category management on retailer prices and performance: Theory and evidence. Journal of Marketing, 65(4), 16-32. https://doi. org/10.1509/jmkg.65.4.16.18382

Bechwati, N. N., Sisodia, R. S., \& Sheth, J. N. (2009). Developing a model of antecedents to consumers' perceptions and evaluations of price unfairness. Journal of Business Research, 62(8), 761-767. https://doi.org/10.1016/j.jbusres.2008.09.004

Benson, E., \& Connell, K. Y. H. (2014). Fair-trade consumption from the perspective of US Baby Boomers. Social 
Responsibility Journal, 10(2), 364-382. https://doi.org/10.1108/ SRJ-08-2012-0094

Bertini, M., \& Wathieu, L. (2008). Research note-Attention arousal through price partitioning. Marketing Science, 27(2), 236-246. https://doi.org/10.1287/mksc. 1070.0295

Bertini, M., \& Wathieu, L. (2010). How to stop customers from fixating on price. Harvard Business Review, 88(5), 84-91.

Bezawada, R., Balachander, S., Kannan, P., \& Shankar, V. (2009). Cross-category effects of aisle and display placements: A spatial modeling approach and insights. Journal of Marketing, 73(3), 99-117. https://doi.org/10.1509/jmkg.73.3.99

Bissinger, K. (2019). Price fairness: Two-stage comparison of conventional and fair-trade prices. Journal of International Consumer Marketing, 31(2), 86-97. https://doi.org/10.1080/08961530. 2018.1482525

Bolton, L. E., Keh, H. T., \& Alba, J. W. (2010). How do price fairness perceptions differ across culture? Journal of Marketing Research, 47(3), 564-576. https://doi.org/10.1509/jmkr.47.3.564

Brown, J., Hossain, T., \& Morgan, J. (2010). Shrouded attributes and information suppression: Evidence from the Field. Quarterly Journal of Economics, 125(2), 859-876. https://doi.org/10.1162/ qjec.2010.125.2.859

Cailleba, P., \& Casteran, H. (2010). Do ethical values work? A quantitative study of the impact of fair-trade coffee on consumer behavior. Journal of Business Ethics, 97(4), 613-624. https://doi.org/ 10.1007/s10551-010-0528-8

Campbell, C. L., Heinrich, D., \& Schoenmüller, V. (2015). Consumers' reaction to fair-trade motivated price increases. Journal of Retailing and Consumer Services, 24(C), 79-84. https://doi.org/ 10.1016/j.jretconser.2015.02.005

Carlson, J. P., \& Weathers, D. (2008). Examining differences in consumer reactions to partitioned prices with a variable number of price components. Journal of Business Research, 61(7), 724731. https://doi.org/10.1016/j.jbusres.2007.09.005

Carlsson, F., García, J. H., \& Löfgren, Å. (2010). Conformity and the demand for environmental goods. Environmental and Resource Economics, 47(3), 407-421. https://doi.org/10.1007/ s10640-010-9385-2

Castaldo, S., Perrini, F., Misani, N., \& Tencati, A. (2009). The missing link between corporate social responsibility and consumer trust: The case of fair-trade products. Journal of Business Ethics, 84(1), 1-15. https://doi.org/10.1007/s10551-008-9669-4

Chakravarti, D., Krish, R., Paul, P., \& Srivastava, J. (2002). Partitioned presentation of multicomponent bundle prices: Evaluation, choice and underlying processing effects. Journal of Consumer Psychology, 12(3), 215-229. https://doi.org/10.1207/15327 6602760335068

Chen, Y.-S., \& Chang, C.-H. (2013). Greenwash and green trust: The mediation effects of green consumer confusion and green perceived risk. Journal of Business Ethics, 114(3), 489-500. https:// doi.org/10.1007/s10551-012-1360-0

Cranfield, J., Henson, S., Northey, J., \& Masakure, O. (2010). An assessment of consumer preference for fair-trade coffee in Toronto and Vancouver. Agribusiness, 26(2), 307-325. https:// doi.org/10.1002/agr.20217

d'Astous, A., \& Mathieu, S. (2008). Inciting consumers to buy fairlytraded products: A field experiment. Journal of Consumer Marketing, 25(3), 149-157. https://doi.org/10.1108/0736376081 0870644

Dahl, R. (2010). Green washing. Environmental Health Perspectives, 118(6), 246-252. https://doi.org/10.1289/ehp.118-a246

Darian, J. C., Tucci, L., Newman, C. M., \& Naylor, L. (2015). An analysis of consumer motivations for purchasing fair-trade coffee. Journal of International Consumer Marketing, 27(4), 318-327. https://doi.org/10.1080/08961530.2015.1022920
Davidson, A., Nepomuceno, M. V., \& Laroche, M. (2019). Shame on you: When materialism leads to purchase intentions toward counterfeit products. Journal of Business Ethics, 155(2), 479-494. https://doi.org/10.1007/s10551-017-3479-5

De Pelsmacker, P., \& Janssens, W. (2007). A model for fair-trade buying behaviour: The role of perceived quantity and quality of information and of product-specific attitudes. Journal of Business Ethics, 75(4), 361-380. https://doi.org/10.1007/ s10551-006-9259-2

De Pelsmacker, P., Driesen, L., \& Rayp, G. (2005a). Do consumers care about ethics? Willingness-to-pay for fair-trade coffee. Journal of Consumer Affairs, 39(2), 363-385. https://doi.org/10.1111/j. 1745-6606.2005.00019.x

De Pelsmacker, P., Janssens, W., Sterckx, E., \& Mielants, C. (2005b). Consumer preferences for the marketing of ethically labelled coffee. International Marketing Review, 22(5), 512-530. https://doi. org/10.1108/02651330510624363

Delmas, M. A., \& Burbano, V. C. (2011). The drivers of greenwashing. California Management Review, 54(1), 64-87. https://doi.org/10. 1525/cmr.2011.54.1.64

Dhar, S. K., Hoch, S. J., \& Kumar, N. (2001). Effective category management depends on the role of the category. Journal of Retailing, 77(2), 165-184. https://doi.org/10.1016/S0022-4359(01) 00045-8

Didier, T., \& Lucie, S. (2008). Measuring consumer's willingness-topay for organic and fair-trade products. International Journal of Consumer Studies, 32(5), 479-490. https://doi.org/10.1111/j. 1470-6431.2008.00714.x

Doney, P. M., \& Cannon, J. P. (1997). An examination of the nature of trust in buyer-seller relationships. Journal of Marketing, 61(2), 35. https://doi.org/10.2307/1251829

Doran, C. J. (2009). The role of personal values in fair-trade consumption. Journal of Business Ethics, 84(4), 549-563. https://doi.org/ 10.1007/s10551-008-9724-1

Døskeland, T., \& Pedersen, L. J. T. (2016). Investing with brain or heart? A field experiment on responsible investment. Management Science, 62(6), 1632-1644. https://doi.org/10.1287/mnsc. 2015.2208

Estelami, H. (1999). The computational effect of price endings in multi-dimensional price advertising. Journal of Product \& Brand Management, 8(3), 244-256. https://doi.org/10.1108/ 10610429910272547

Fair-Trade Foundation. (2021a). Key benefits of fair-trade. Retrieved November 12, 2019, from https://www.fairtrade.net/about/keybenefits-of-fairtrade

Fair-Trade Foundation. (2021b). The fair-trade marks. Retrieved April 11, 2021, from https://info.fairtrade.net/what/the-fairtrade-marks

Fair-Trade Foundation. (2021c). Cocoa. Retrieved November 14, 2019, from https://www.fairtrade.net/product/cocoa

Fair-Trade Foundation. (2021d). Bananas. Retrieved November 14, 2019, from https://www.fairtrade.net/product/bananas

Fair-Trade Foundation. (2021e). Pricing table. Retrieved November 12, 2019, from https://www.fairtrade.net/standard/minim um-price-info

Ferguson, J. L. (2014). Implementing price increases in turbulent economies: Pricing approaches for reducing perceptions of price unfairness. Journal of Business Research, 67(1), 2732-2737. https://doi.org/10.1016/j.jbusres.2013.03.023

Ferguson, J. L., \& Ellen, P. S. (2013). Transparency in pricing and its effect on perceived price fairness. Journal of Product \& Brand Management, 22(5/6), 404-412. https://doi.org/10.1108/ JPBM-06-2013-0323

Folkes, V. S. (1988). The availability heuristic and perceived risk. Journal of Consumer Research, 15(1), 13. https://doi.org/10.1086/ 209141 
Galarraga, I., \& Markandya, A. (2011). Economic techniques to estimate the demand for sustainable products: A case study for fair trade and organic coffee in the United Kingdom. Economía Agraria y Recursos Naturales, 4(7), 109. https://doi.org/10.7201/ earn.2004.07.06

Gleim, M. R., Smith, J. S., Andrews, D., \& Cronin, J. J. (2013). Against the green: A multi-method examination of the barriers to green consumption. Journal of Retailing, 89(1), 44-61. https://doi.org/ 10.1016/j.jretai.2012.10.001

Gracia, A. (2014). Consumers' preferences for a local food product: A real choice experiment. Empirical Economics, 47(1), 111-128. https://doi.org/10.1007/s00181-013-0738-x

Greenleaf, E. A., Johnson, E. J., Morwitz, V. G., \& Shalev, E. (2016). The price does not include additional taxes, fees, and surcharges: A review of research on partitioned pricing. Journal of Consumer Psychology, 26(1), 105-124. https://doi.org/10.1016/j.jcps.2015. 04.006

Hamilton, R. W., \& Srivastava, J. (2008). When $2+2$ is not the same as $1+3$ : Variations in price sensitivity across components of partitioned prices. Journal of Marketing Research, 45(4), 450-461. https://doi.org/10.1509/jmkr.45.4.450

Hanna, R. C., Lemon, K. N., \& Smith, G. E. (2019). Is transparency a good thing? How online price transparency and variability can benefit firms and influence consumer decision making. Business Horizons, 62(2), 227-236. https://doi.org/10.1016/j.bushor.2018. 11.006

Haws, K. L., Liu, P. J., Dallas, S. K., Cawley, J., \& Roberto, C. A. (2020). Any size for a dollar: The effect of any-size-same-price versus standard pricing on beverage size choices. Journal of Consumer Psychology, 30(2), 392-401. https://doi.org/10.1002/jcpy. 1129

Hayes, A. F. (2018). Introduction to mediation, moderation and conditional process analysis. A regression-based approach. The Guilford Press.

Hertel, S., Scruggs, L., \& Heidkamp, C. P. (2009). Human rights and public opinion: From attitudes to action. Political Science Quarterly, 124(3), 443-459.

Holmes, J. H., \& Crocker, K. E. (1987). Predispositions and the comparative effectiveness of rational, emotional and discrepant appeals for both high involvement and low involvement products. Journal of the Academy of Marketing Science, 15(1), 27-35. https://doi.org/10.1177/009207038701500104

Homburg, C., Totzek, D., \& Krämer, M. (2014). How price complexity takes its toll: The neglected role of a simplicity bias and fairness in price evaluations. Journal of Business Research, 67(6), 1114-1122. https://doi.org/10.1016/j.jbusres.2013.05.049

Hoppe, A., Vieira, L. M., \& de Barcellos, M. D. (2013). Consumer behaviour towards organic food in porto alegre: An application of the theory of planned behaviour. Revista De Economia e Sociologia Rural, 51(1), 69-90. https://doi.org/10.1590/S0103-20032 013000100004

Howard, P. H., \& Allen, P. (2008). Consumer willingness-to-pay for domestic 'fair-trade': Evidence from the United States. Renewable Agriculture and Food Systems, 23(03), 235-242. https://doi. org/10.1017/S1742170508002275

Howard, P. H., \& Allen, P. (2010). Beyond organic and fair trade? An analysis of ecolabel preferences in the United States. Rural Sociology, 75(2), 244-269. https://doi.org/10.1111/j.1549-0831. 2009.00009.x

Ingenbleek, P. T. M. (2015). Price strategies for sustainable food products. British Food Journal, 117(2), 915-928. https://doi.org/10. 1108/BFJ-02-2014-0066

Johnstone, M.-L., \& Tan, L. P. (2015). Exploring the gap between consumers' green rhetoric and purchasing behaviour. Journal of Business Ethics, 132(2), 311-328. https://doi.org/10.1007/ s10551-014-2316-3
Kahneman, D., \& Tversky, A. (1979). Prospect theory: An analysis of decision under risk. Econometrica, 47, 263.

Kapusuz, S., \& Kimzan, H. S. (2016). The role of fair-trade trust on the relationship of fair-trade knowledge, fair-trade adhesion, and willingness-to-pay fair-trade premium: The case of Turkey. Turkish Journal of Business Ethics, 9(1), 70-89. https://doi.org/10. 12711/tjbe.2016.9.0019

Kim, H. M. (2006). The effect of salience on mental accounting: How integration versus segregation of payment influences purchase decisions. Journal of Behavioral Decision Making, 19(4), 381391. https://doi.org/10.1002/bdm.534

Koukova, N. T., Srivastava, J., \& Steul-Fischer, M. (2012). The effect of shipping fee structure on consumers' online evaluations and choice. Journal of the Academy of Marketing Science, 40(6), 759-770. https://doi.org/10.1007/s11747-011-0281-2

Langer, A., Eisend, M., \& Ku, A. (2008). The impact of eco-labels on consumers: Less information, more confusion? European Advances in Consumer Research, 8, 338-339.

Lee, Y. H., \& Han, C. Y. (2002). Partitioned pricing in advertising: Effects on brand and retailer attitudes. Marketing Letters, 13(1), 27-40. https://doi.org/10.1023/A:1015011108224

Loureiro, M. L., \& Lotade, J. (2005). Do fair-trade and eco-labels in coffee wake up the consumer conscience? Ecological Economics, 53(1), 129-138. https://doi.org/10.1016/j.ecolecon.2004.11.002

Louviere, J. J., Hensher, D. A., \& Swait, J. D. (2000). Stated choice methods: Analysis and applications. Cambridge University Press.

Lusk, J. L., \& Schroeder, T. C. (2004). Are choice experiments incentive compatible? A test with quality differentiated beef steaks. American Journal of Agricultural Economics, 86(2), 467-482. https://doi.org/10.1111/j.0092-5853.2004.00592.x

Lyn Cox, J. (2001). Can differential prices be fair? Journal of Product \& Brand Management, 10(5), 264-275. https://doi.org/10.1108/ 10610420110401829

Manning, K. C., \& Sprott, D. E. (2009). Price endings, left-digit effects, and choice. Journal of Consumer Research, 36(2), 328-335. https://doi.org/10.1086/597215

Marconi, N. G., Hooker, N. H., \& DiMarcello, N. (2017). What's in a name? The impact of fair-trade claims on product price. Agribusiness, 33(2), 160-174. https://doi.org/10.1002/agr.21486

Matzler, K., Renzl, B., \& Faullant, R. (2007). Dimensions of price satisfaction: A replication and extension. International Journal of Bank Marketing, 25(6), 394-405. https://doi.org/10.1108/02652 320710820345

Matzler, K., Würtele, A., \& Renzl, B. (2006). Dimensions of price satisfaction: A study in the retail banking industry. International Journal of Bank Marketing, 24(4), 216-231. https://doi.org/10. $1108 / 02652320610671324$

McMurtry, J. J. (2009). Ethical value-added: Fair-trade and the case of Café Femenino. Journal of Business Ethics, 86(S1), 27-49. https://doi.org/10.1007/s10551-008-9760-x

Michaud, C., Llerena, D., \& Joly, I. (2013). Willingness-to-pay for environmental attributes of non-food agricultural products: A real choice experiment. European Review of Agricultural Economics, 40(2), 313-329. https://doi.org/10.1093/erae/jbs025

Moore, G. (2004). The fair-trade movement: Parameters, issues and future research. Journal of Business Ethics, 53(1/2), 73-86. https://doi.org/10.1023/B:BUSI.0000039400.57827.c3

Morwitz, V. G., Greenleaf, E. A., \& Johnson, E. J. (1998). Divide and prosper: Consumers' reactions to partitioned prices. Journal of Marketing Research, 35(4), 453. https://doi.org/10.2307/3152164

Moser, A. K. (2015). Thinking green, buying green? Drivers of pro-environmental purchasing behavior. Journal of Consumer Marketing, 32(3), 167-175. https://doi.org/10.1108/ JCM-10-2014-1179

Nyilasy, G., Gangadharbatla, H., \& Paladino, A. (2014). Perceived greenwashing: The interactive effects of green advertising and 
corporate environmental performance on consumer reactions. Journal of Business Ethics, 125(4), 693-707. https://doi.org/10. 1007/s10551-013-1944-3

Page, B., Trinh, G., \& Bogomolova, S. (2019). Comparing two supermarket layouts: The effect of a middle aisle on basket size, spend, trip duration and endcap use. Journal of Retailing and Consumer Services, 47(November 2018), 49-56. https://doi.org/10.1016/j. jretconser.2018.11.001

Parguel, B., Benoît-Moreau, F., \& Larceneux, F. (2011). How sustainability ratings might deter 'greenwashing': A closer look at ethical corporate communication. Journal of Business Ethics, 102(1), 15-28. https://doi.org/10.1007/s10551-011-0901-2

Pedregal, V. D., \& Ozcaglar-Toulouse, N. (2011). Why does not everybody purchase fair-trade products? The question of the fairness of fair-trade products' consumption for consumers. International Journal of Consumer Studies, 35(6), 655-660. https://doi.org/10. 1111/j.1470-6431.2010.00990.x

Peer, E., Brandimarte, L., Samat, S., \& Acquisti, A. (2017). Beyond the Turk: Alternative platforms for crowdsourcing behavioral research. Journal of Experimental Social Psychology, 70, 153163. https://doi.org/10.1016/j.jesp.2017.01.006

Rashid, M. S., \& Byun, S.-E. (2018). Are consumers willing to go the extra mile for fair-trade products made in a developing country? A comparison with made in USA products at different prices. Journal of Retailing and Consumer Services, 41(December 2017), 201-210. https://doi.org/10.1016/j.jretconser.2017.12.011

Rios, K., Finkelstein, S. R., \& Landa, J. (2015). Is there a "fair" in fairtrade? Social dominance orientation influences perceptions of and preferences for fair-trade products. Journal of Business Ethics, 130(1), 171-180. https://doi.org/10.1007/s10551-014-2221-9

Rousu, M. C., \& Corrigan, J. R. (2008). Estimating the welfare loss to consumers when food labels do not adequately inform: An application to fair-trade certification. Journal of Agricultural \& Food Industrial Organization. https://doi.org/10.2202/1542-0485.1212

Schwarz, N., Bless, H., Strack, F., Klumpp, G., et al. (1991). Ease of retrieval as information: Another look at the availability heuristic. Journal of Personality and Social Psychology, 61(2), 195-202. https://doi.org/10.1037/0022-3514.61.2.195

Sheng, S., Bao, Y., \& Pan, Y. (2007). Partitioning or bundling? Perceived fairness of the surcharge makes a difference. Psychology and Marketing, 24(12), 1025-1041. https://doi.org/10.1002/mar. 20194

Statista. (2018). Fairly traded products market in the United States. Retrieved November 13, 2019, from https://www-statista-com. revproxy.escpeurope.eu/study/12462/fairly-trade-products-market-in-the-united-states-statista-dossier/

Statista. (2021). Statista consumer market outlook-Food Report 2021. Retrieved 10 July 2021, https://www-statista-com.revproxy.escpe urope.eu/study/55496/food-report-2021/

Stratton, J. P., \& Werner, M. J. (2013). Consumer behavior analysis of fair-trade coffee: Evidence from field research. The Psychological Record, 63(2), 363-374. https://doi.org/10.11133/j.tpr.2013. 63.2.010
Street, D. J., Burgess, L., \& Louviere, J. J. (2005). Quick and easy choice sets: Constructing optimal and nearly optimal stated choice experiments. International Journal of Research in Marketing, 22(4), 459-470. https://doi.org/10.1016/j.ijresmar.2005. 09.003

Trudel, R., \& Cotte, J. (2009). Does it pay to be good ? MIT Sloan Management Review, 50(2), 61.

Tversky, A., \& Kahneman, D. (1973). Availability: A heuristic for judging frequency and probability. Cognitive Psychology, 5(2), 207-232. https://doi.org/10.1016/0010-0285(73)90033-9

Uusitalo, O., \& Oksanen, R. (2004). Ethical consumerism: A view from Finland. International Journal of Consumer Studies, 28(3), 214-221. https://doi.org/10.1111/j.1470-6431.2003.00339.x

van Herpen, E., van Nierop, E., \& Sloot, L. (2012). The relationship between in-store marketing and observed sales for organic versus fair-trade products. Marketing Letters, 23(1), 293-308. https:// doi.org/10.1007/s11002-011-9154-1

Voester, J., Ivens, B., \& Leischnig, A. (2017). Partitioned pricing: Review of the literature and directions for further research. Review of Managerial Science, 11(4), 879-931. https://doi.org/ 10.1007/s11846-016-0208-x

Wathieu, L., \& Bertini, M. (2007). Price as a stimulus to think: The case for willful overpricing. Marketing Science, 26(1), 118-129. https://doi.org/10.1287/mksc.1060.0222

Weiner, B. (1986). An attributional theory of motivation and emotion. Land development studies (Vol. 4). Springer. https://doi.org/10. 1007/978-1-4612-4948-1

Xia, L., \& Monroe, K. B. (2004). Price partitioning on the Internet. Journal of Interactive Marketing, 18(4), 63-73. https://doi.org/ 10.1002/dir.20017

Xia, L., \& Monroe, K. B. (2010). Is a good deal always fair? Examining the concepts of transaction value and price fairness. Journal of Economic Psychology, 31(6), 884-894. https://doi.org/10.1016/j. joep.2010.07.001

Xia, L., Monroe, K. B., \& Cox, J. L. (2004). The price is unfair! A conceptual framework of price fairness perceptions. Journal of Marketing, 68(4), 1-15. https://doi.org/10.1509/jmkg.68.4.1.42733

Yadav, M. S. (1994). How buyers evaluate product bundles: A model of anchoring and adjustment. Journal of Consumer Research, 21(2), 342. https://doi.org/10.1086/209402

Yang, S.-H., Hu, W., Mupandawana, M., \& Liu, Y. (2012). Consumer willingness-to-pay for fair-trade coffee: A chinese case study. Journal of Agricultural and Applied Economics, 44(1), 21-34. https://doi.org/10.1017/S1074070800000146

Yue, C., \& Tong, C. (2009). Organic or local? Investigating consumer preference for fresh produce using a choice experiment with real economic incentives. HortScience, 44(2), 366-371. https://doi. org/10.21273/HORTSCI.44.2.366

Publisher's Note Springer Nature remains neutral with regard to jurisdictional claims in published maps and institutional affiliations. 